\title{
Mallopenins A-E, Antibacterial Phenolic Derivatives from the Fruits of Mallotus philippensis
}

Sarot Cheenpracha,,$" \pitchfork$ Stephen G. Pyne, ${ }^{\ddagger}$ Raymond J. Andersen, ${ }^{\S}$ Brian O. Patrick, ${ }^{\S}$ Wisanu Maneerat ${ }^{\perp \|}$ and Surat Laphookhieo ${ }^{\perp \Perp}$

${ }^{\dagger}$ Division of Chemistry, School of Science, University of Phayao, Maeka, Muang, Phayao 56000, Thailand

\$ School of Chemistry, University of Wollongong, Wollongong, New South Wales 2522, Australia

$\S$ Department of Chemistry and Department of Earth, Ocean, and Atmospheric Sciences, University of British Columbia, 2036 Main Mall, Vancouver, British Columbia, Canada V6T $1 \mathrm{Z1}$

${ }^{\perp}$ Center of Chemical Innovation for Sustainability (CIS), and "School of Science, Mae Fah Luang University, Tasud, Muang, Chiang Rai 57100, Thailand 
Table of Contents

Figure S1. ${ }^{1} \mathrm{H}$ NMR (400 MHz, $\left.\mathrm{CDCl}_{3}\right)$ spectrum of 1.................................................. 4

Figure S2. ${ }^{13} \mathrm{C}$ NMR $\left(100 \mathrm{MHz}, \mathrm{CDCl}_{3}\right.$, spectrum of 1............................................... 4

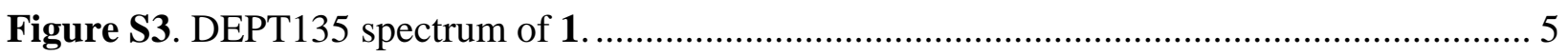

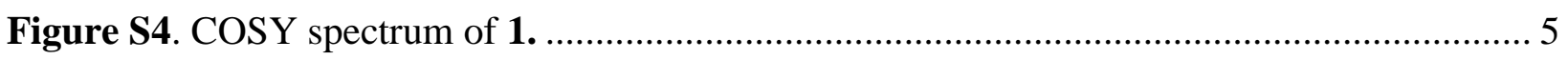

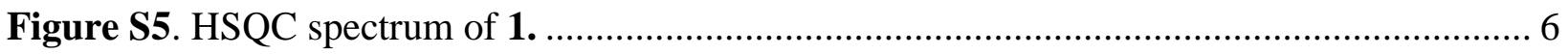

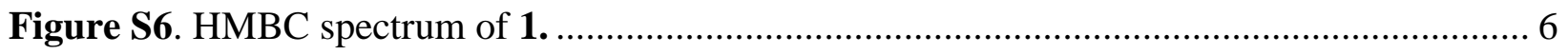

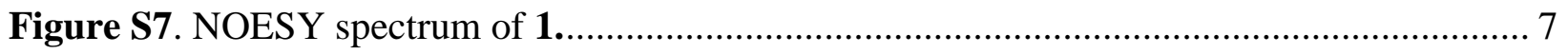

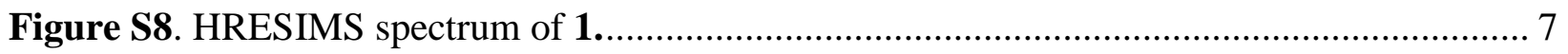

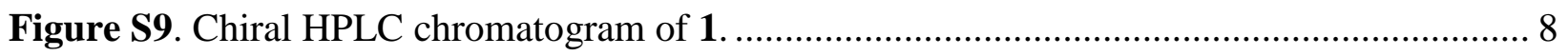

Figure S10. ${ }^{1} \mathrm{H}$ NMR $\left(400 \mathrm{MHz}, \mathrm{CDCl}_{3}\right)$ spectrum of 2. ................................................. 8

Figure S11. ${ }^{13} \mathrm{C}$ NMR $\left(100 \mathrm{MHz}, \mathrm{CDCl}_{3}\right)$ spectrum of 2........................................... 9

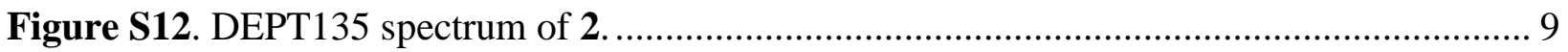

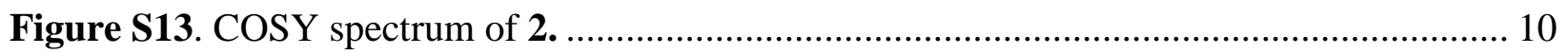

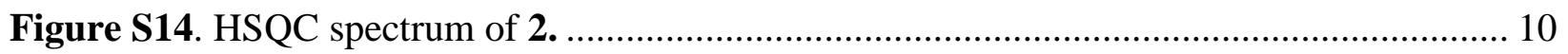

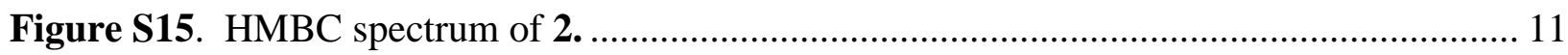

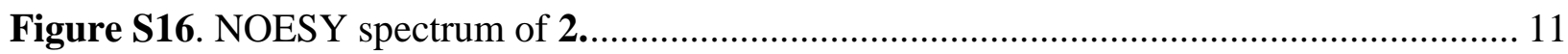

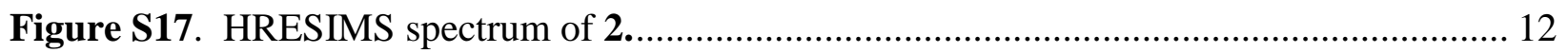

Figure S18. Chiral HPLC chromatogram of 2 .................................................................. 12

Figure S19. ${ }^{1} \mathrm{H}$ NMR (500 MHz, $\left.\mathrm{CDCl}_{3}\right)$ spectrum of 3................................................ 13

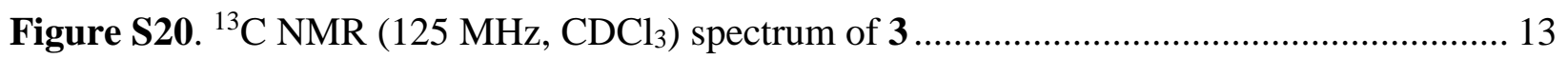

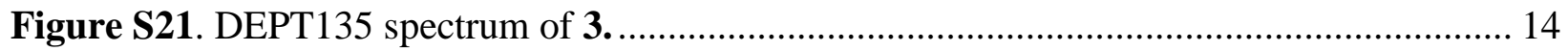

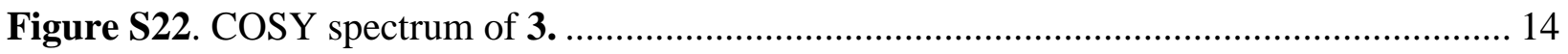

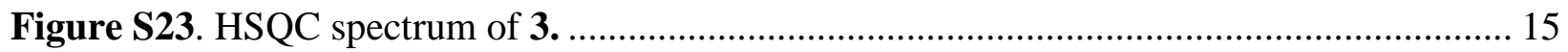

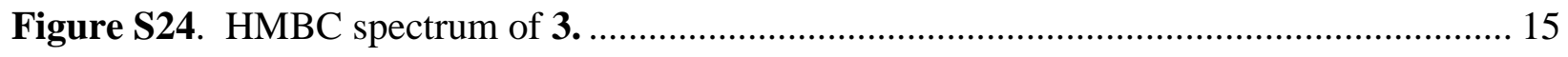

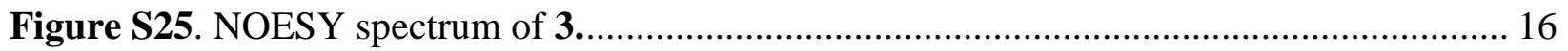

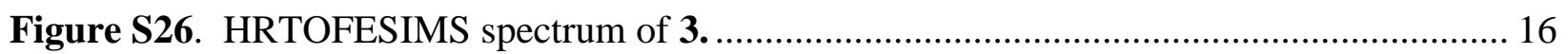

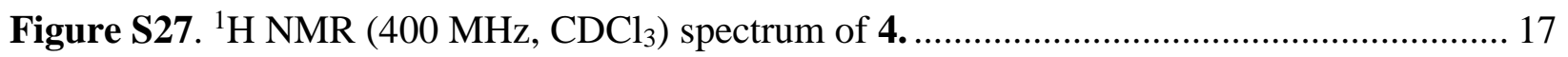

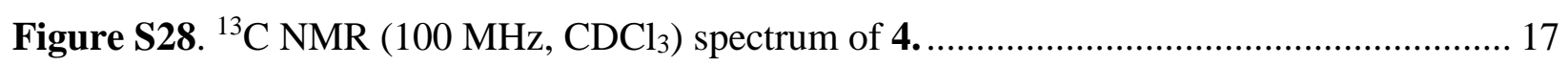

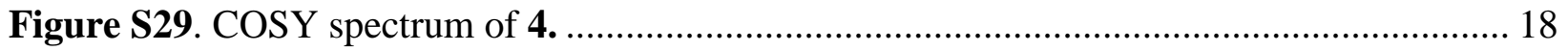

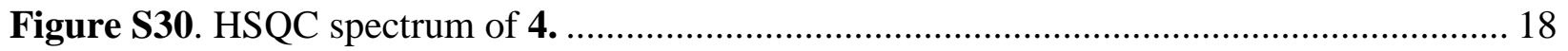

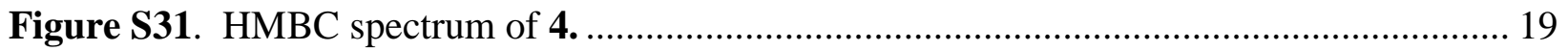




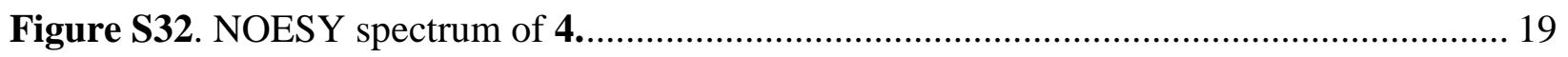

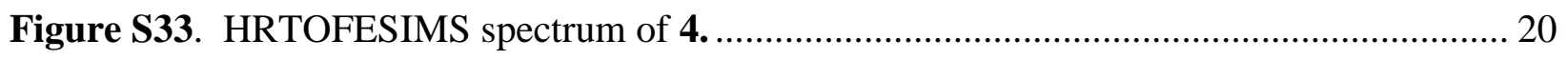

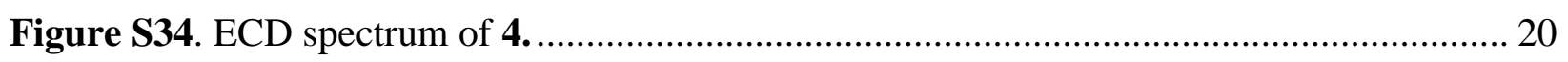

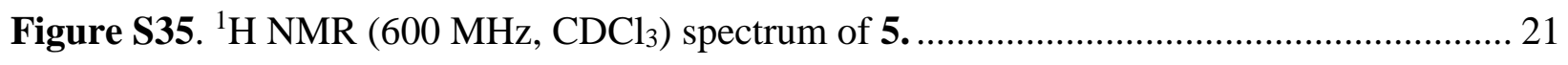

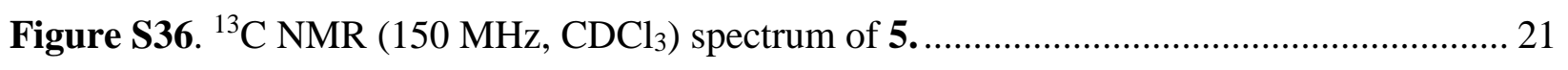

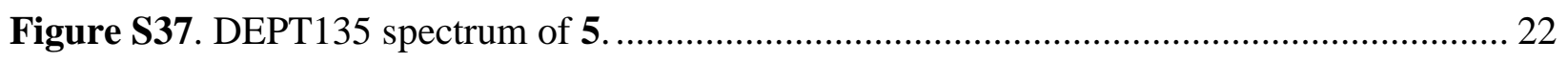

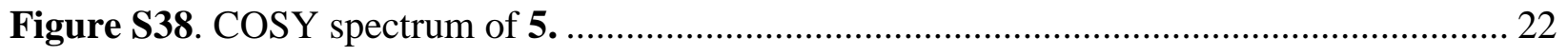

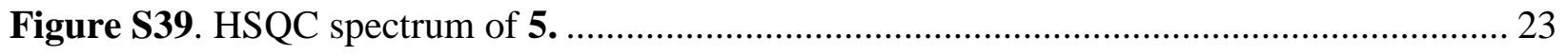

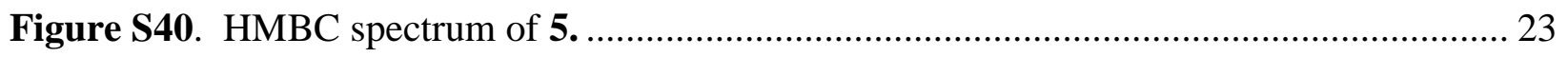

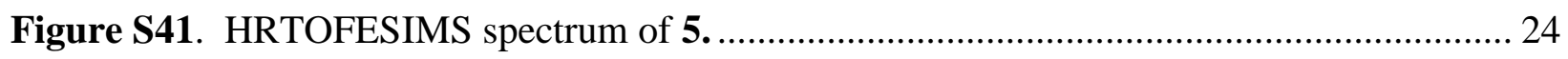

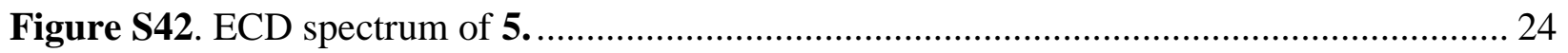




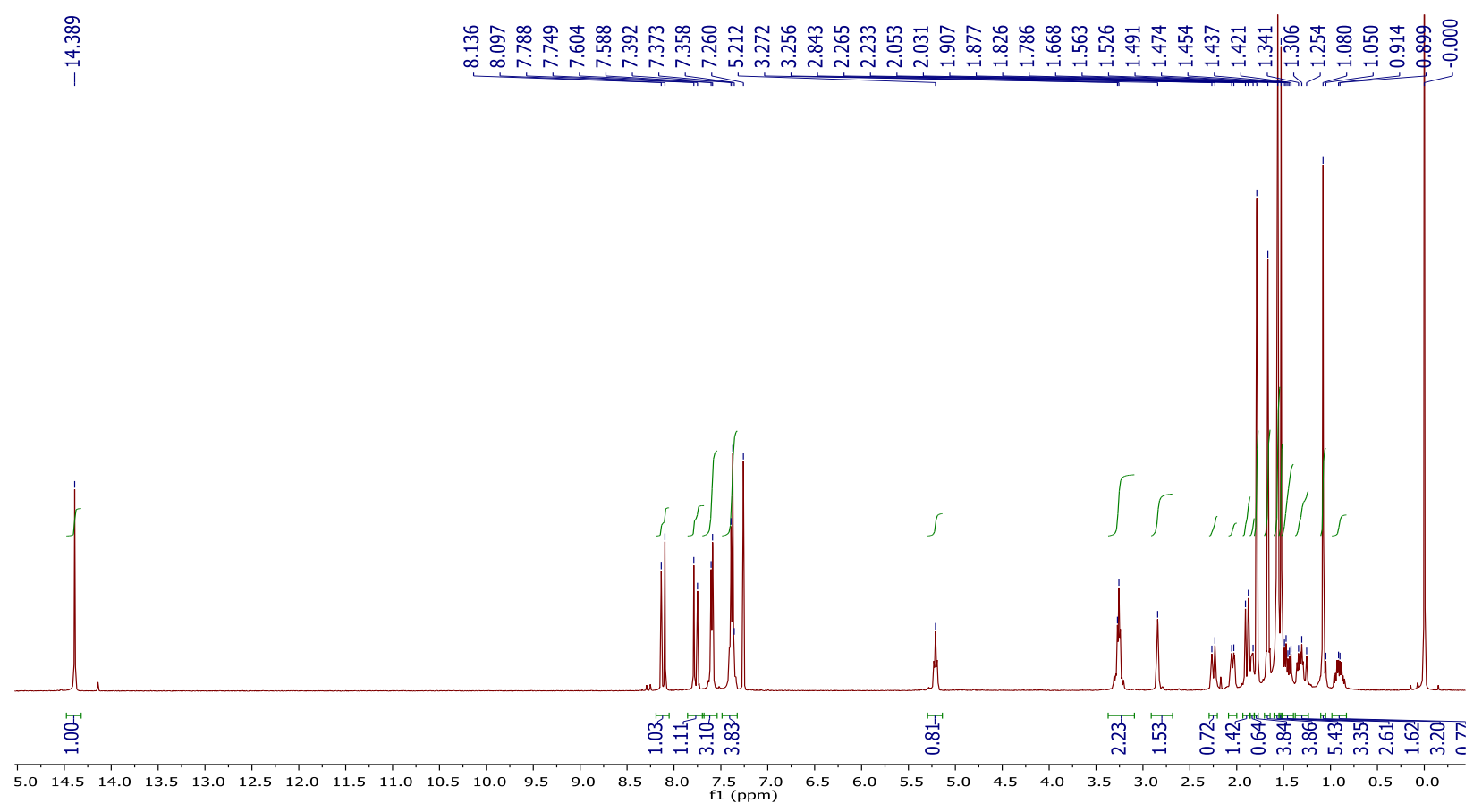

Figure S1. ${ }^{1} \mathrm{H}$ NMR $\left(400 \mathrm{MHz}, \mathrm{CDCl}_{3}\right)$ spectrum of $\mathbf{1}$.

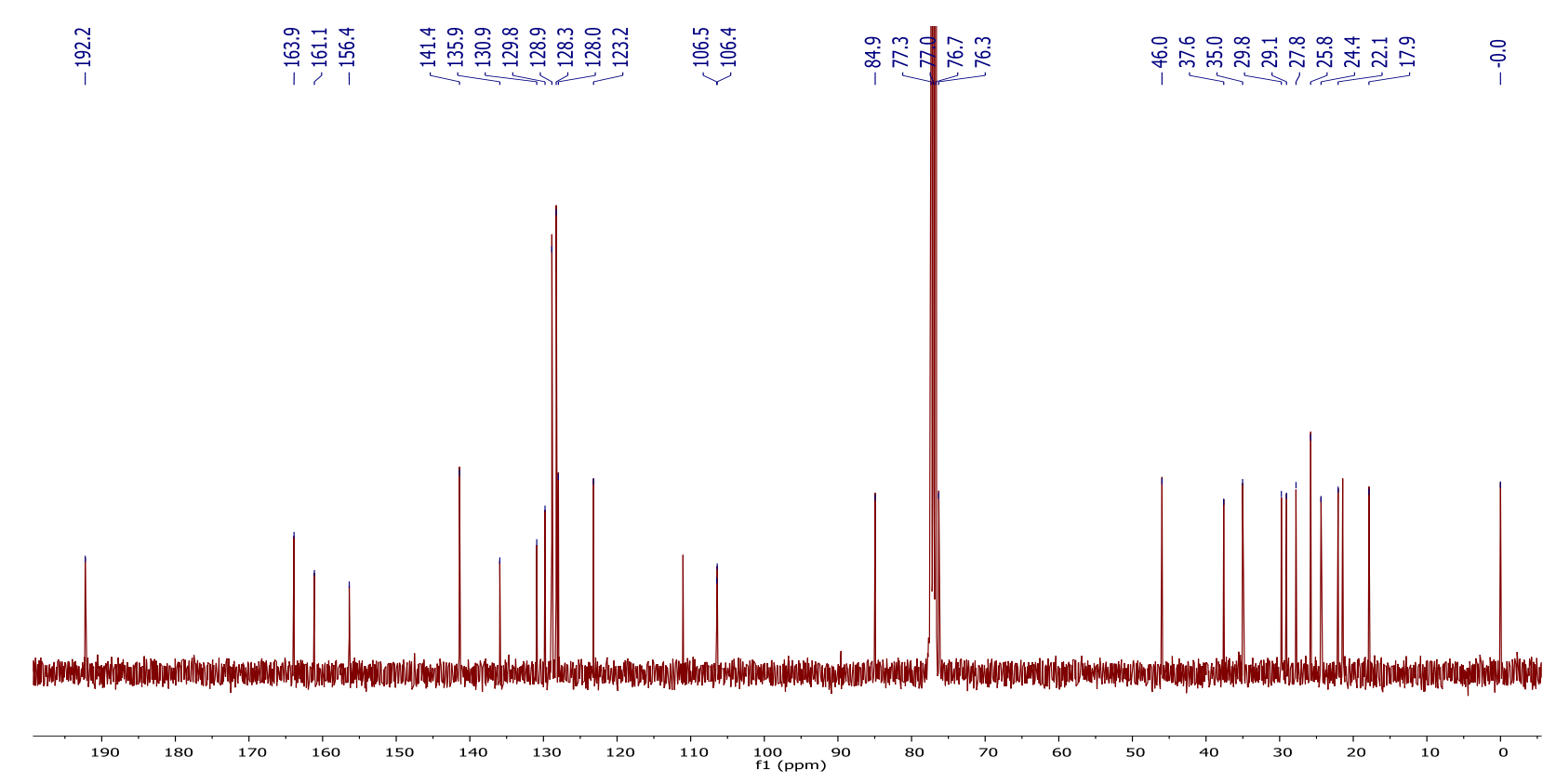

Figure S2. ${ }^{13} \mathrm{C}$ NMR $\left(100 \mathrm{MHz}, \mathrm{CDCl}_{3}\right.$, ) spectrum of $\mathbf{1}$. 


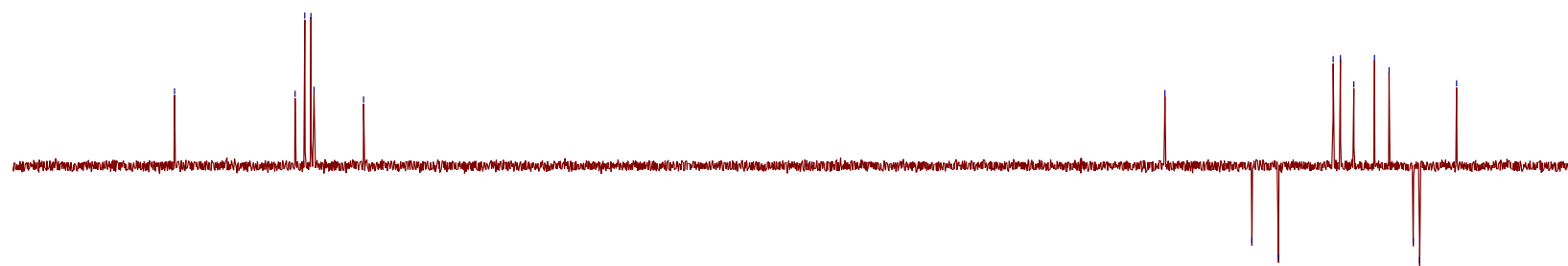

Figure S3. DEPT135 spectrum of 1.

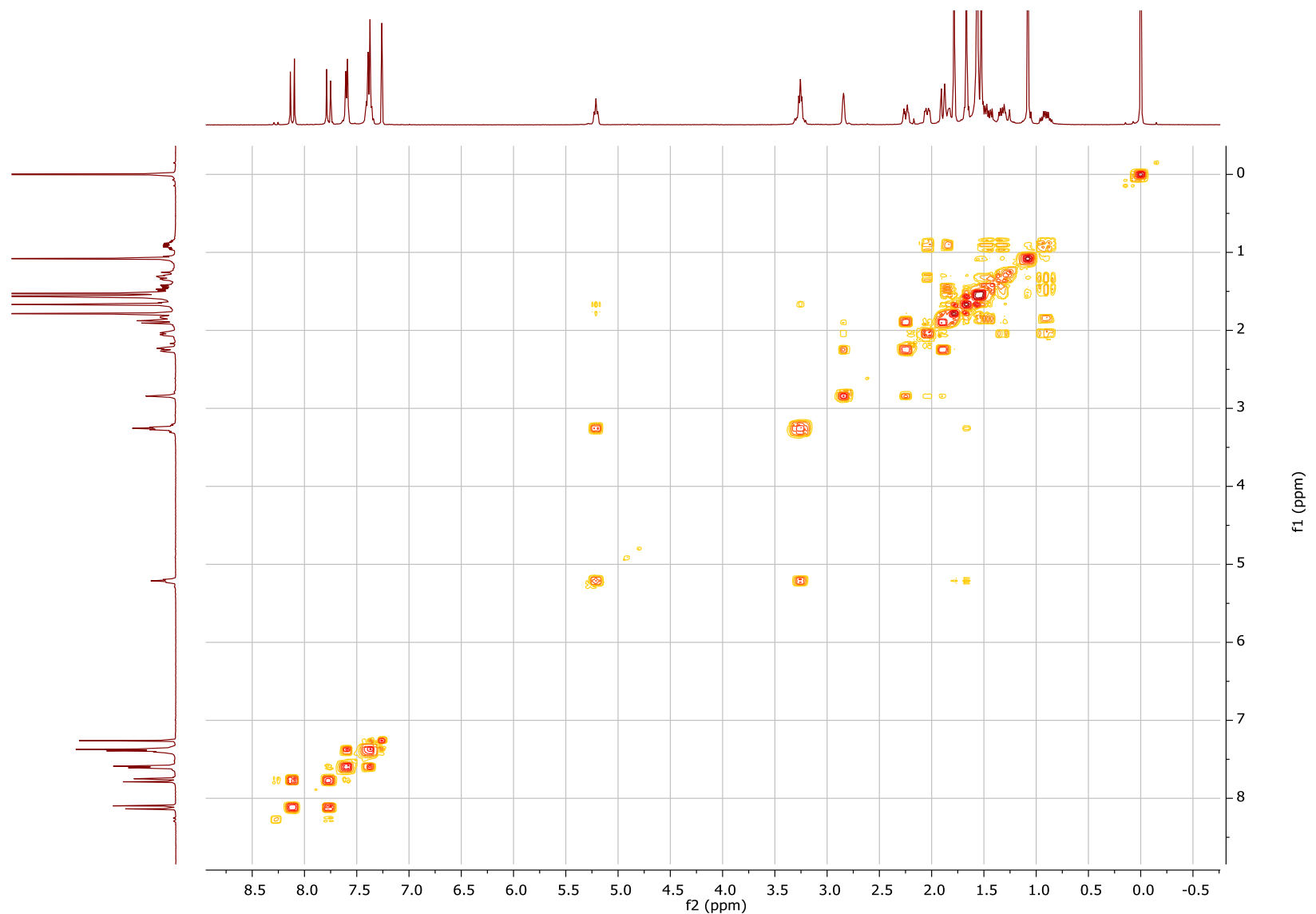

Figure S4. COSY spectrum of $\mathbf{1}$. 


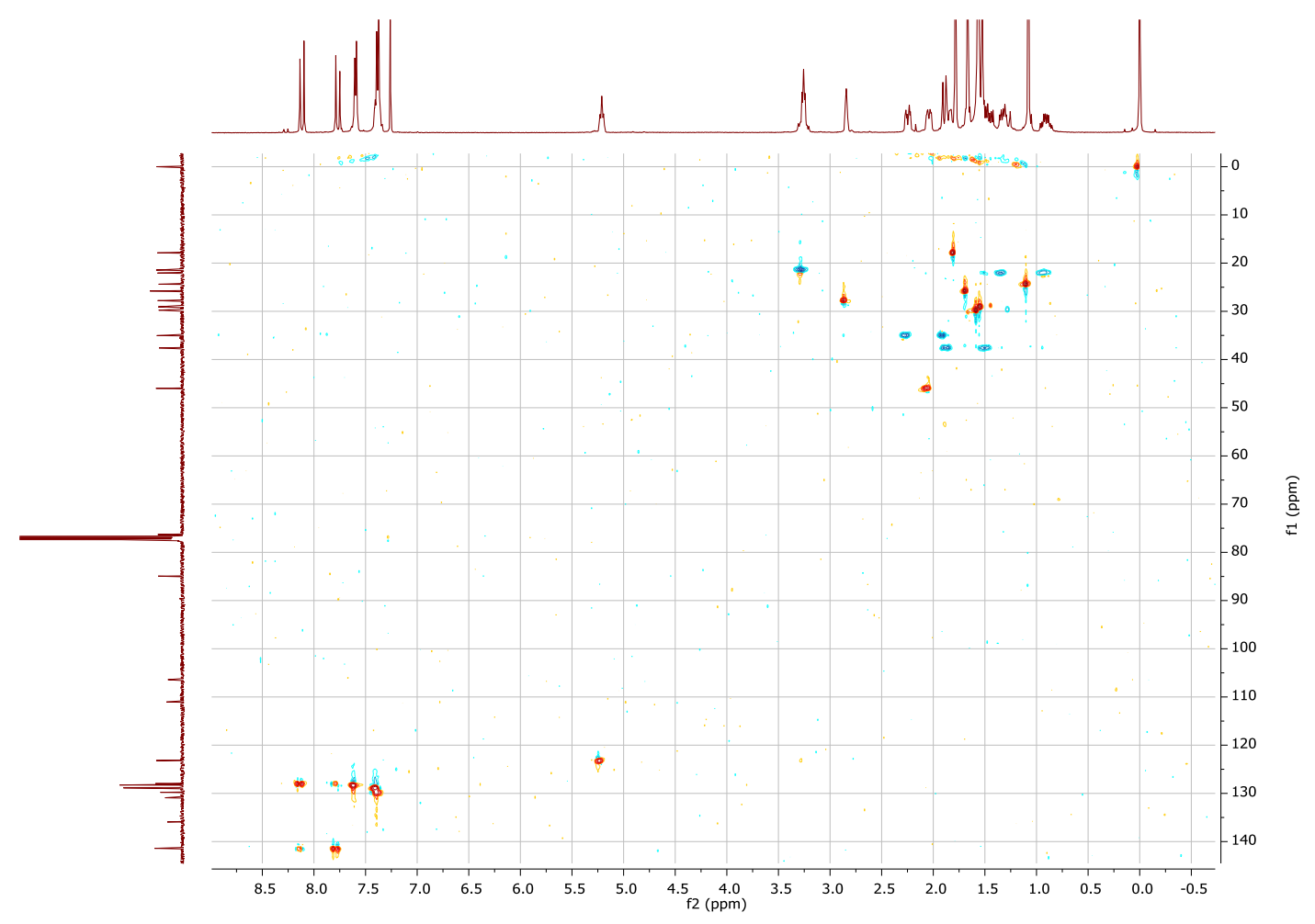

Figure S5. HSQC spectrum of $\mathbf{1}$.

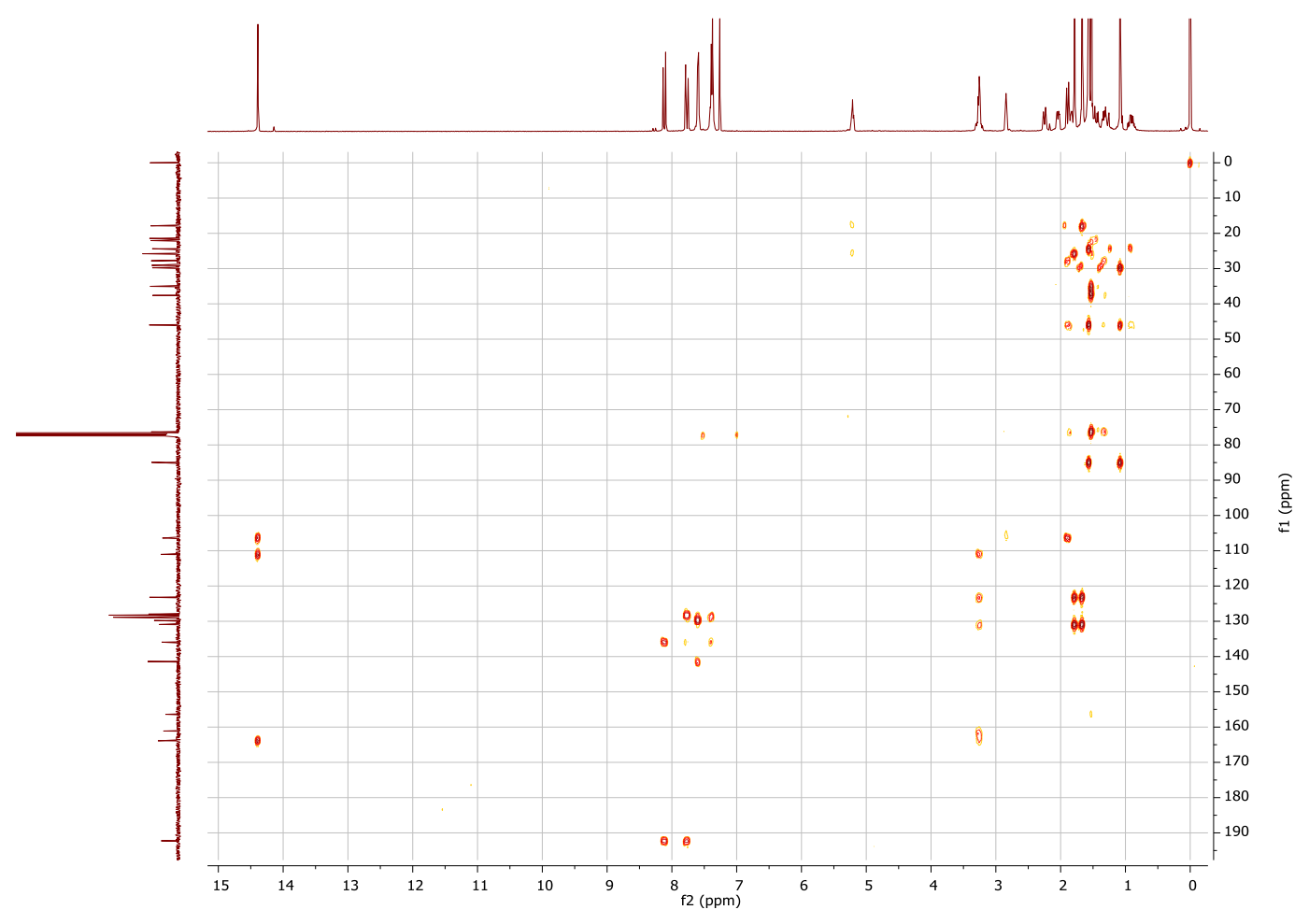

Figure S6. HMBC spectrum of $\mathbf{1}$. 


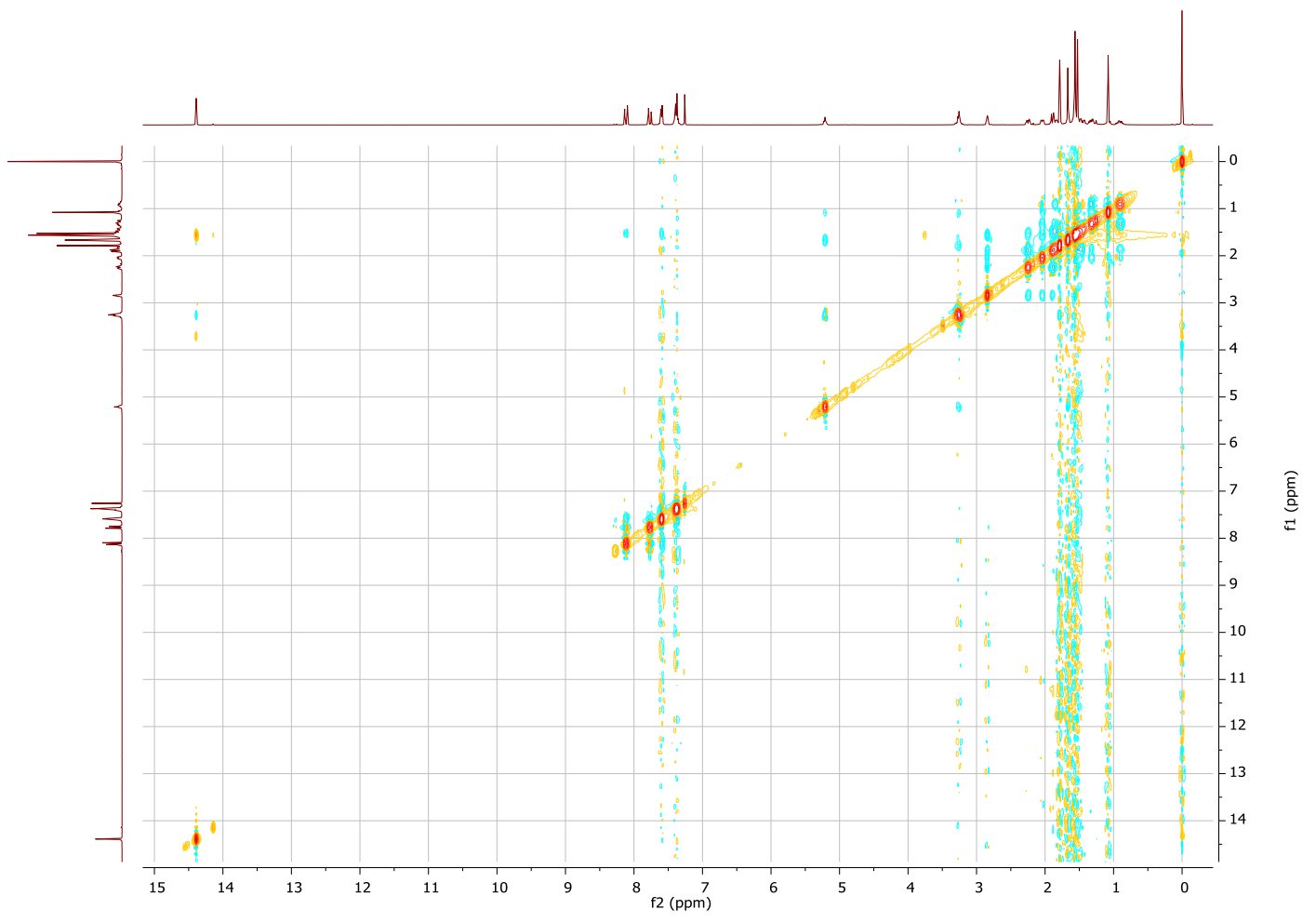

Figure S7. NOESY spectrum of $\mathbf{1}$.

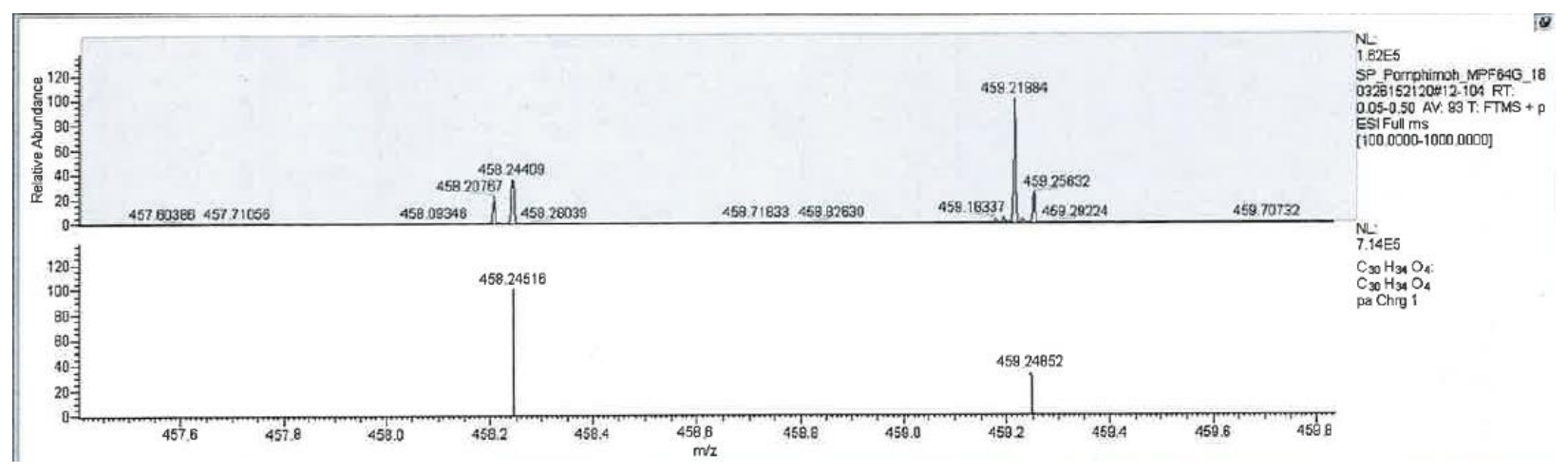

Figure S8. HRESIMS spectrum of $\mathbf{1}$. 


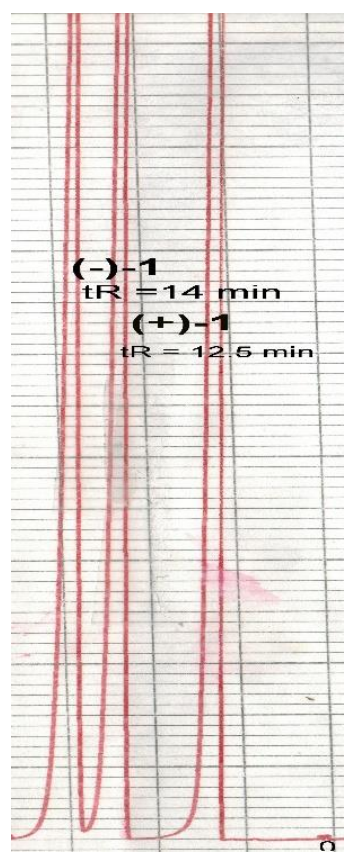

Flow rate: $1.5 \mathrm{ml} / \mathrm{min}$

Mobile phase: $1 \%$ i-PrOH in heaxane

Figure S9. Chiral HPLC chromatogram of 1.

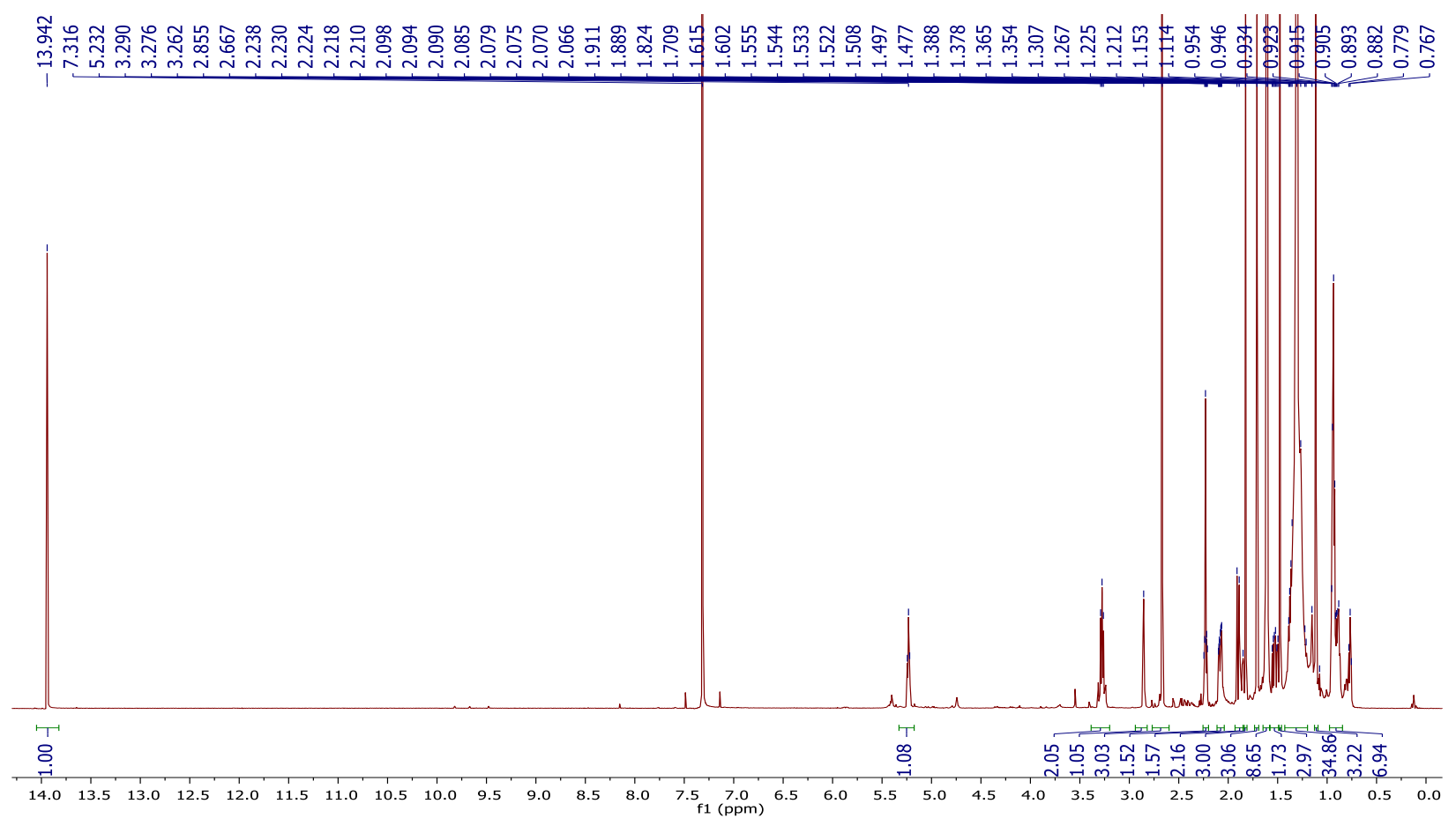

Figure S10. ${ }^{1} \mathrm{H}$ NMR (400 MHz, $\left.\mathrm{CDCl}_{3}\right)$ spectrum of 2. 


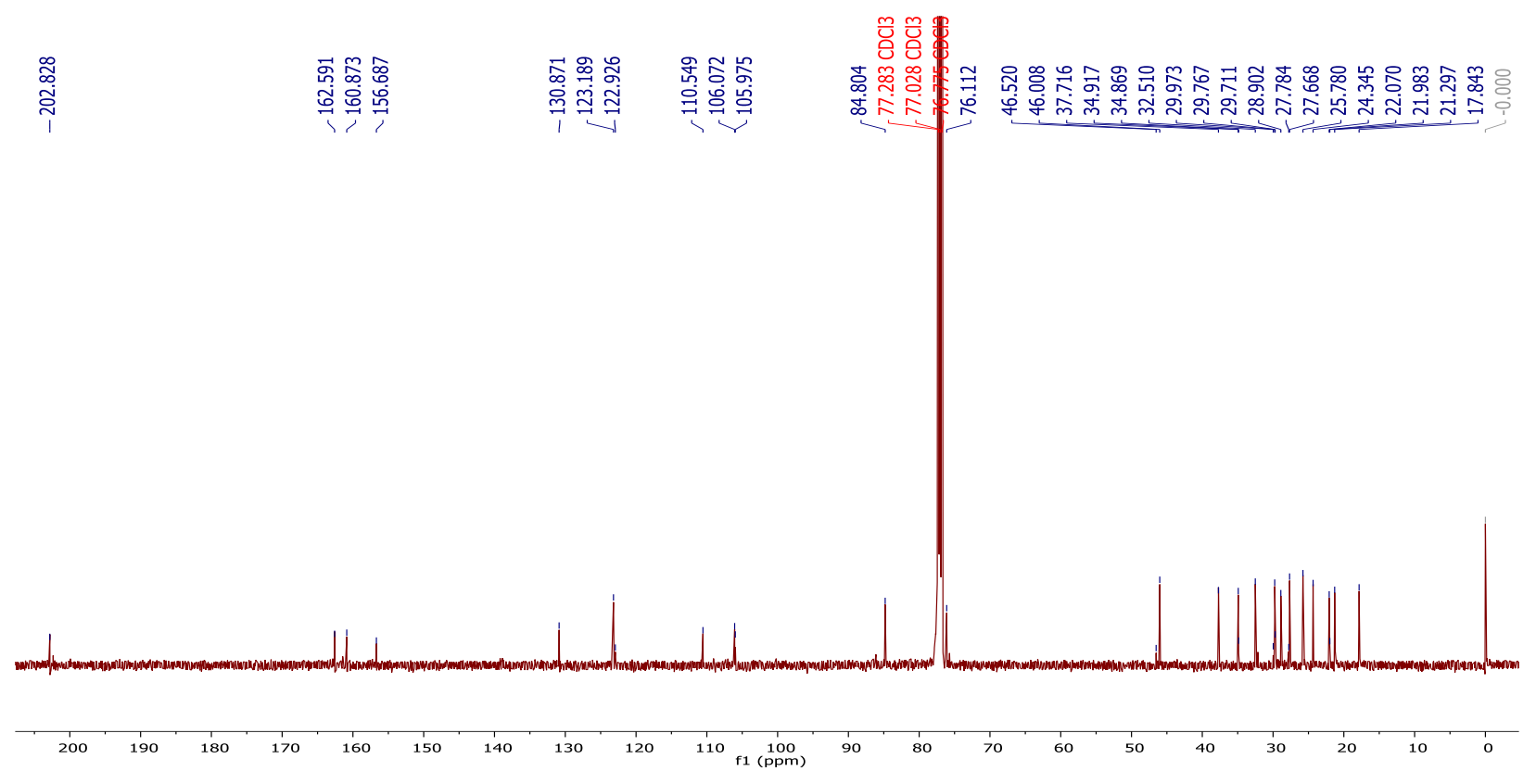

Figure S11. ${ }^{13} \mathrm{C}$ NMR $\left(100 \mathrm{MHz}, \mathrm{CDCl}_{3}\right)$ spectrum of 2.

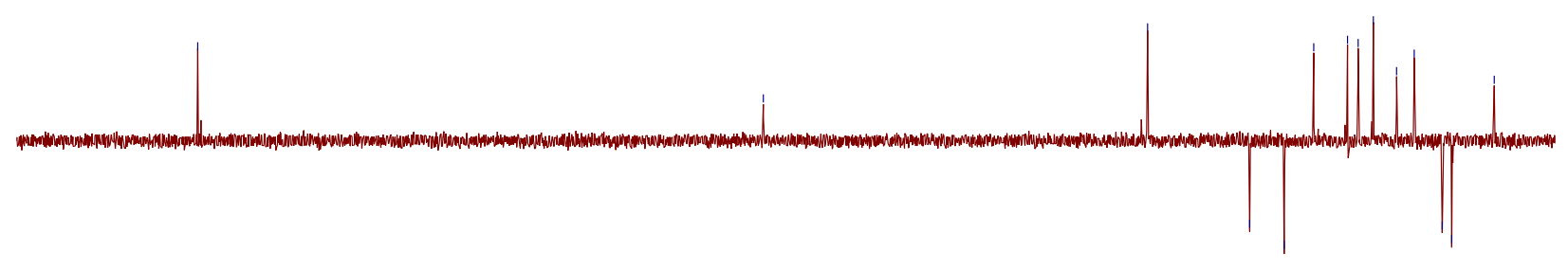

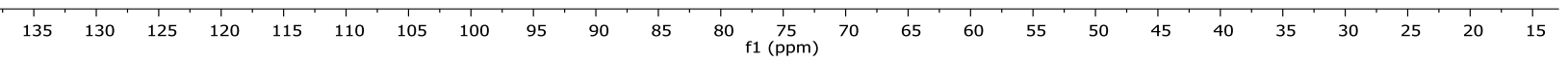

Figure S12. DEPT135 spectrum of 2. 


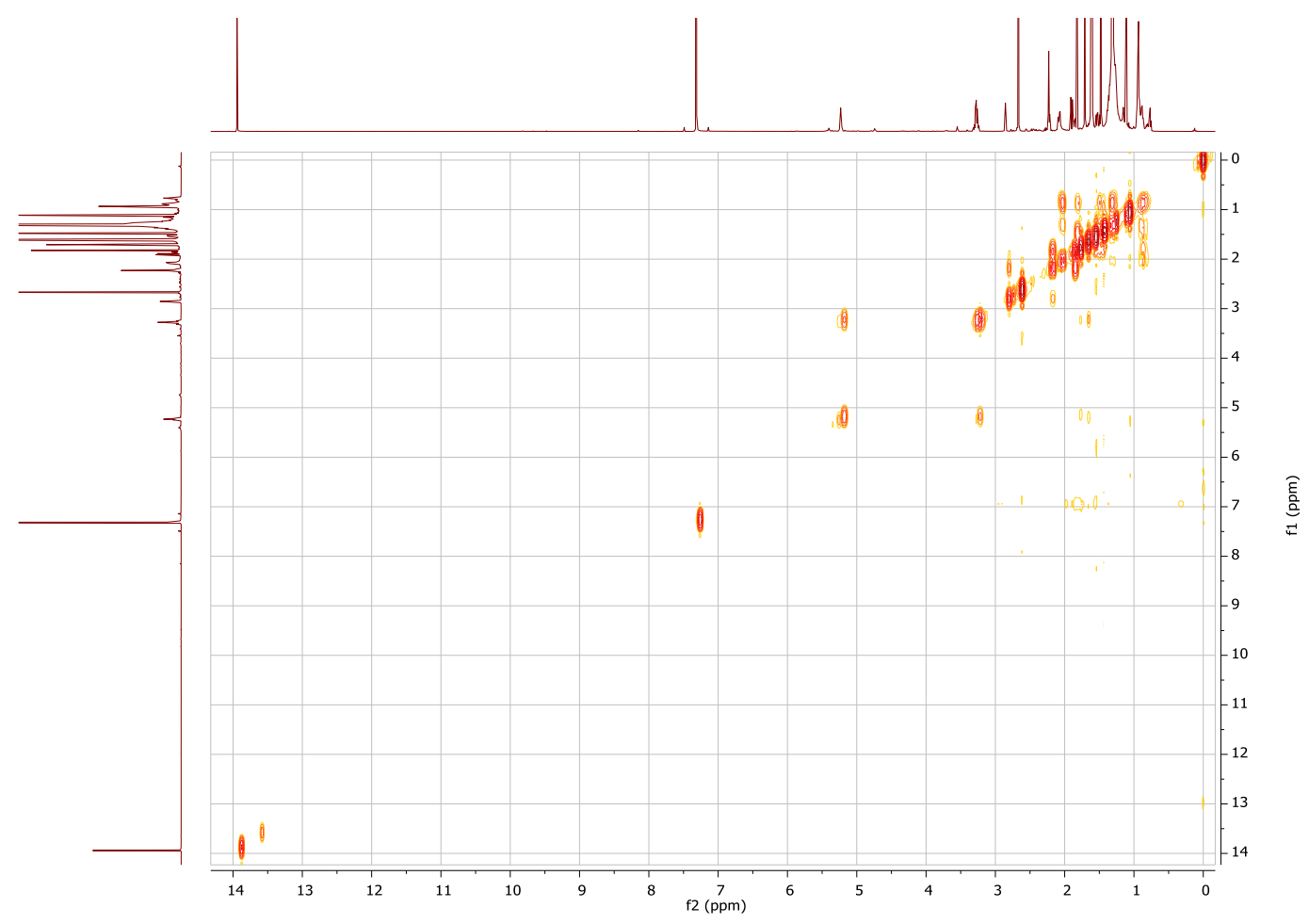

Figure S13. COSY spectrum of 2.

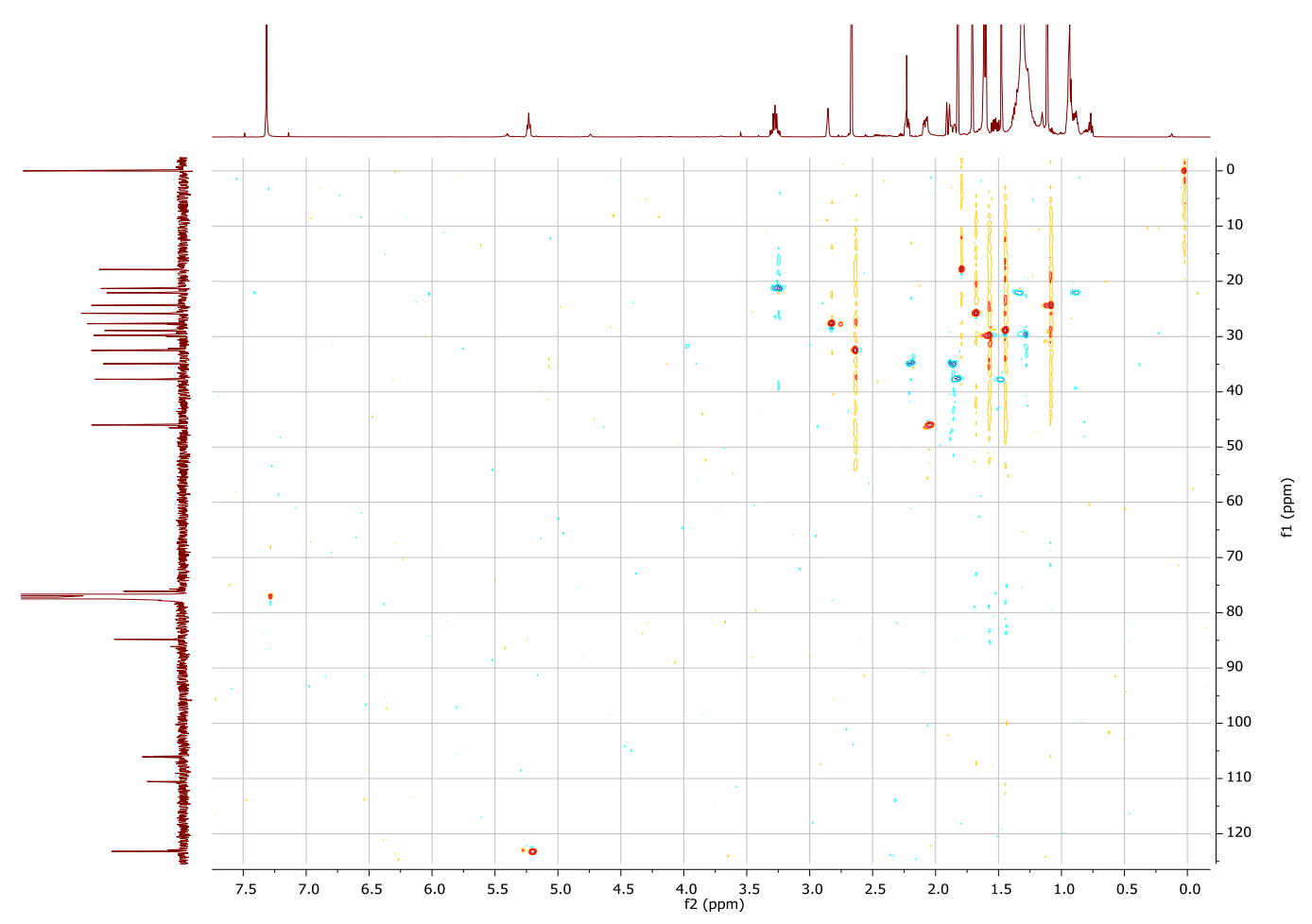

Figure S14. HSQC spectrum of 2. 


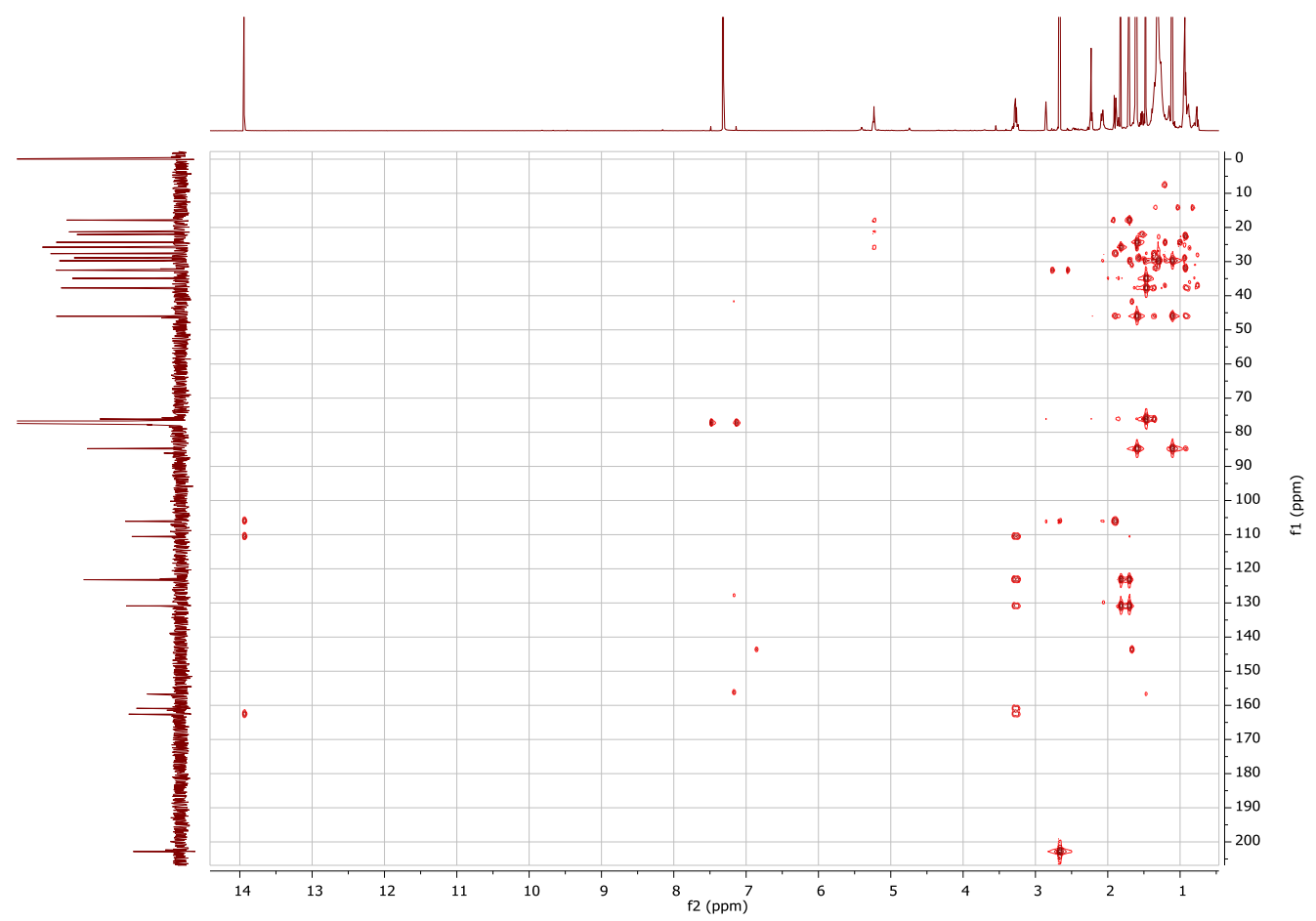

Figure S15. HMBC spectrum of 2.

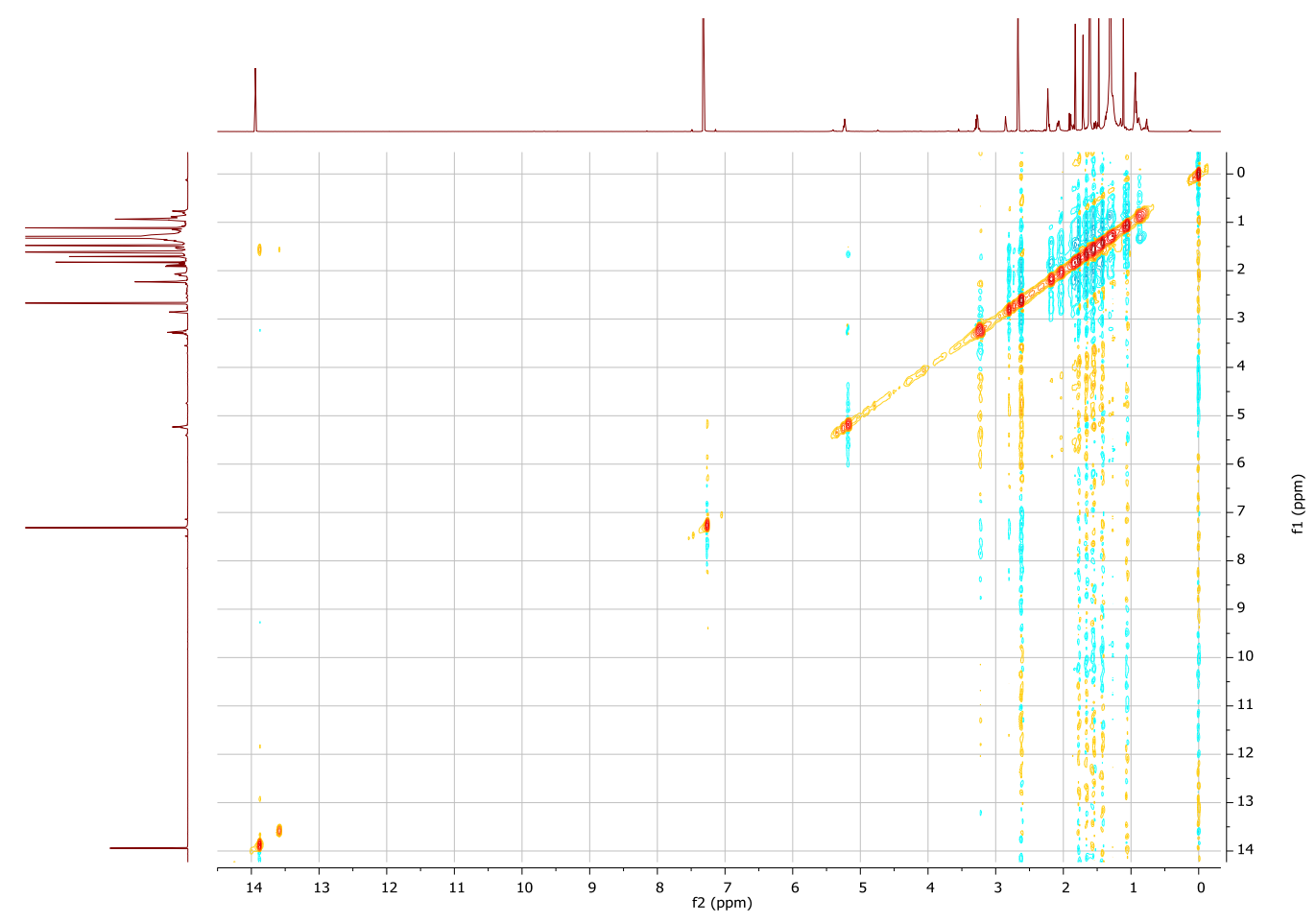

Figure S16. NOESY spectrum of 2. 


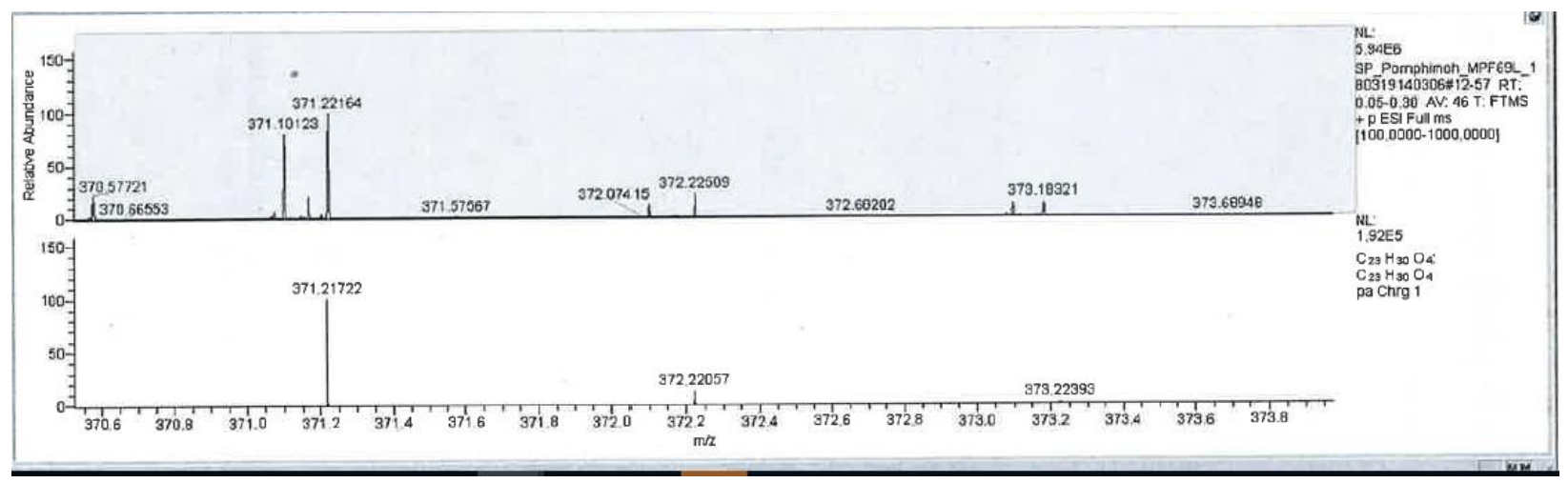

Figure S17. HRESIMS spectrum of 2.

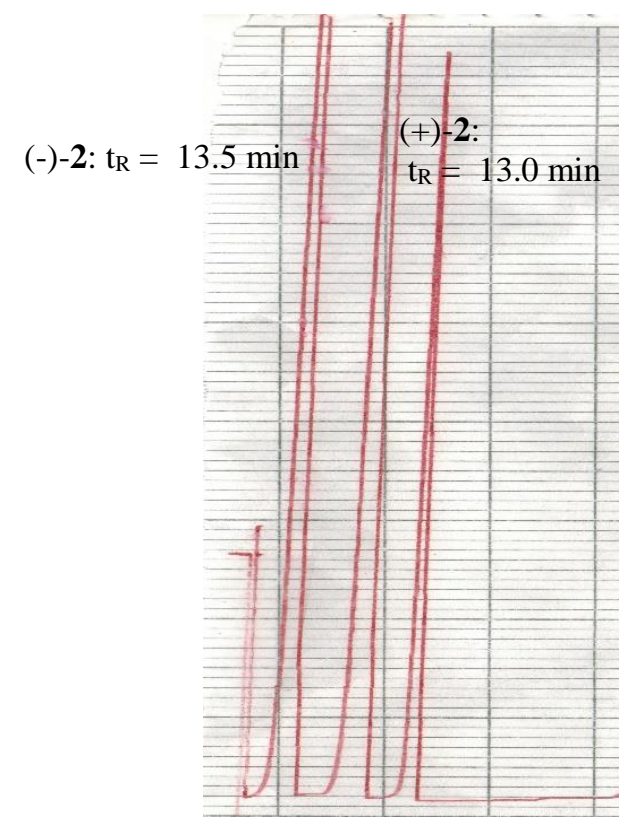

Flow rate: $1.0 \mathrm{ml} / \mathrm{min}$

Mobile phase: $1 \%$ i-PrOH in heaxane

Figure S18. Chiral HPLC chromatogram of 2. 


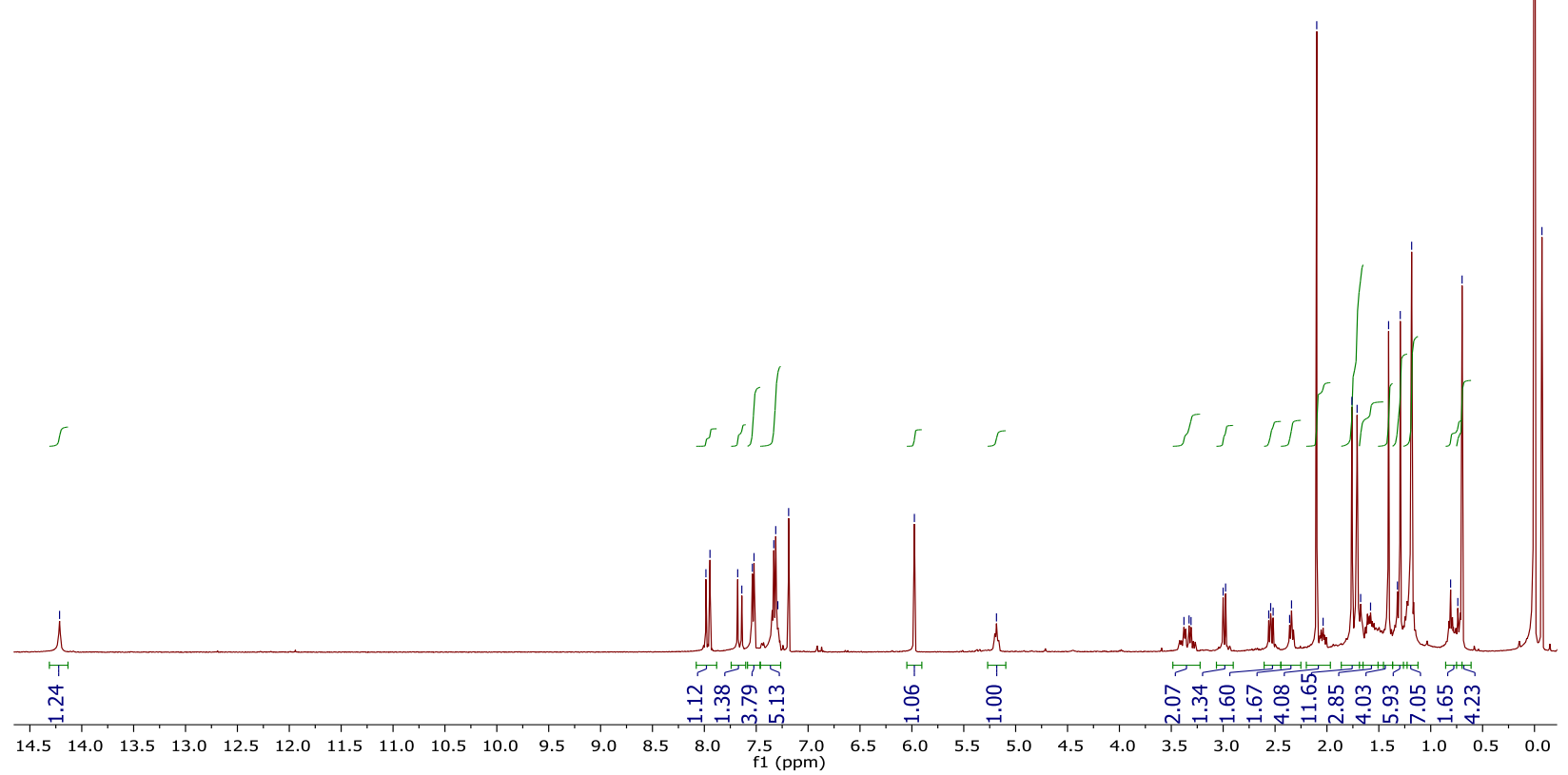

Figure S19. ${ }^{1} \mathrm{H}$ NMR $\left(500 \mathrm{MHz}, \mathrm{CDCl}_{3}\right)$ spectrum of 3.

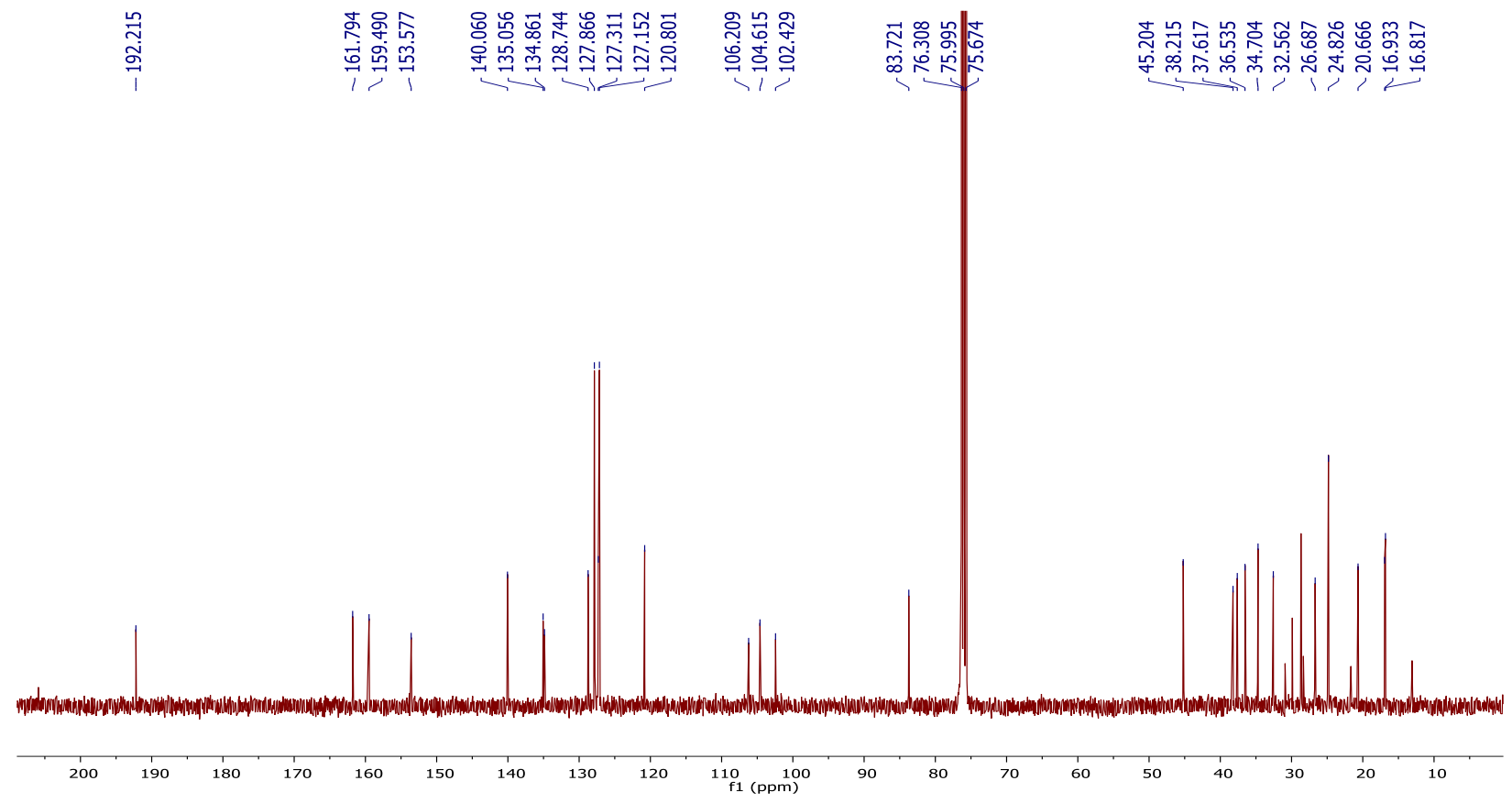

Figure S20. ${ }^{13} \mathrm{C}$ NMR $\left(125 \mathrm{MHz}, \mathrm{CDCl}_{3}\right)$ spectrum of $\mathbf{3}$ 

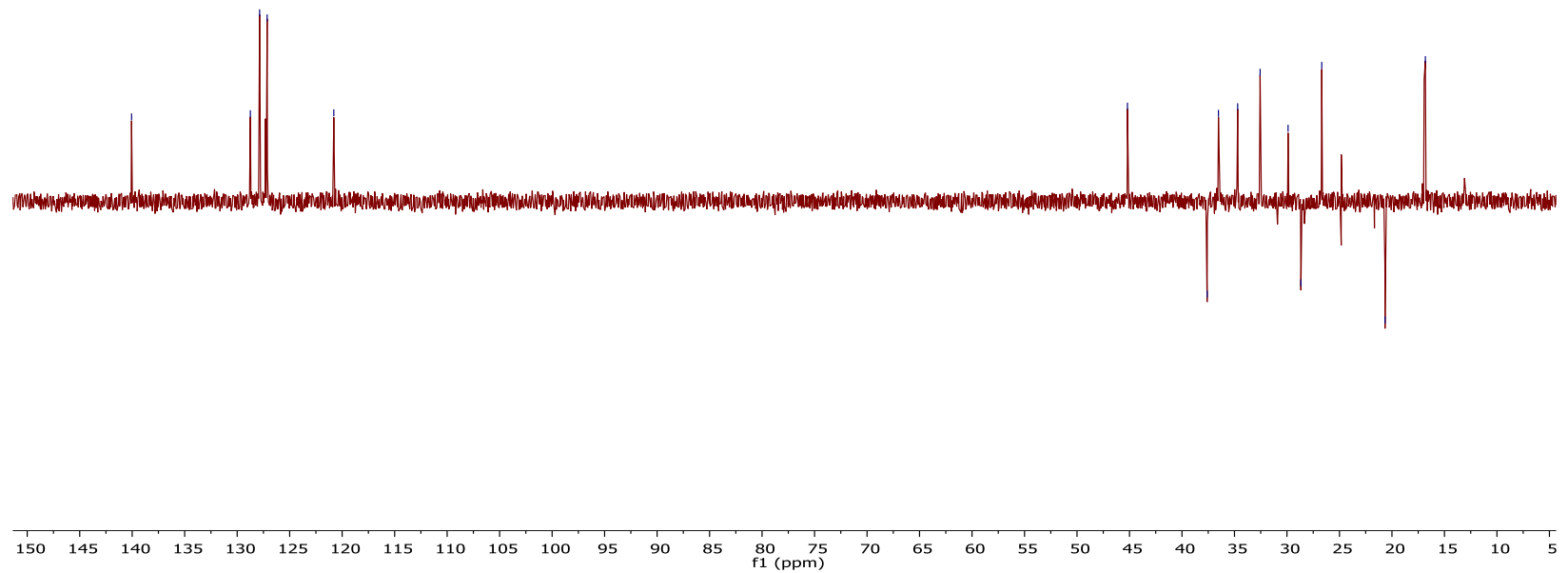

Figure S21. DEPT135 spectrum of 3.

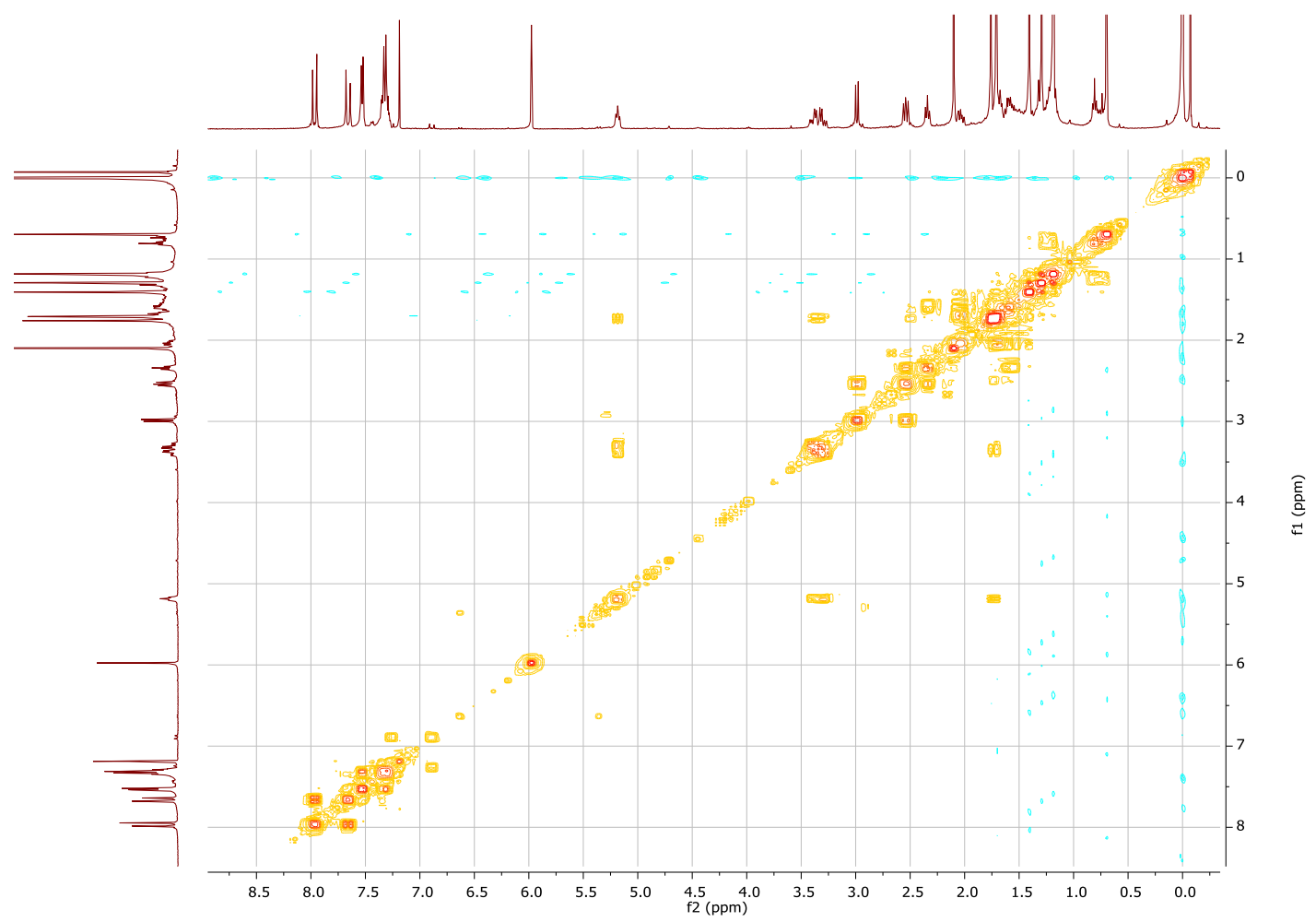

Figure S22. COSY spectrum of $\mathbf{3}$. 


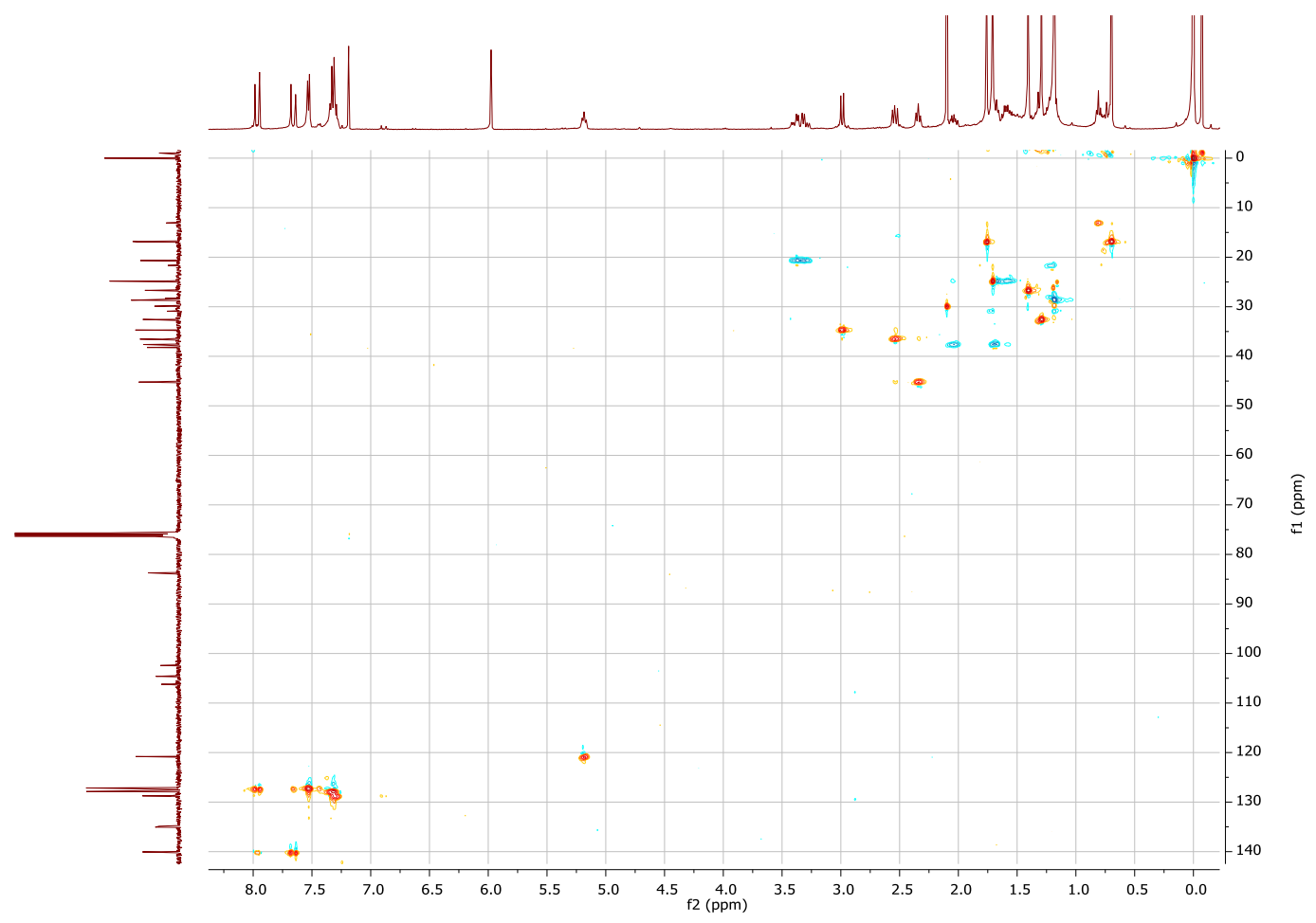

Figure S23. HSQC spectrum of 3.

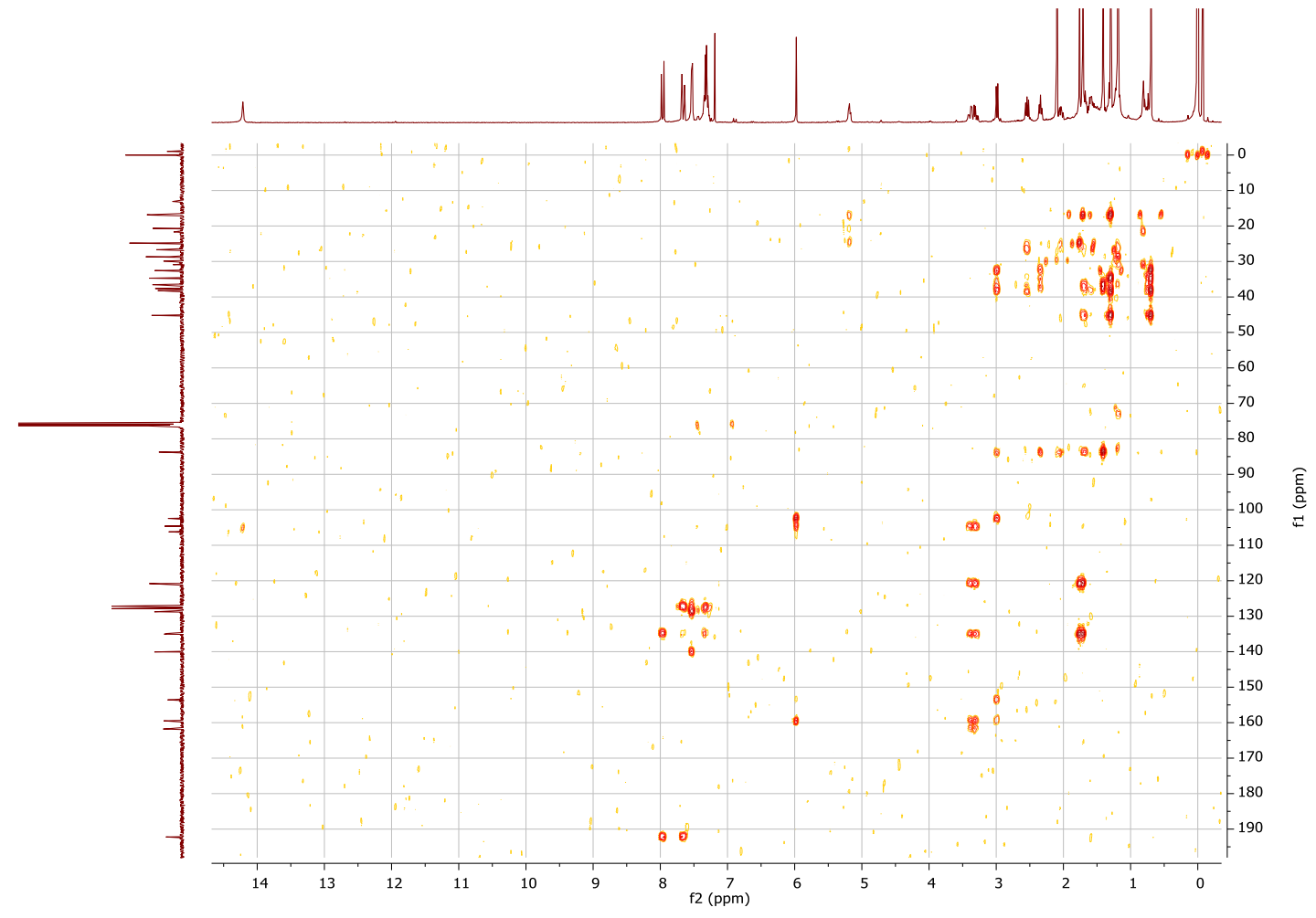

Figure S24. HMBC spectrum of 3. 


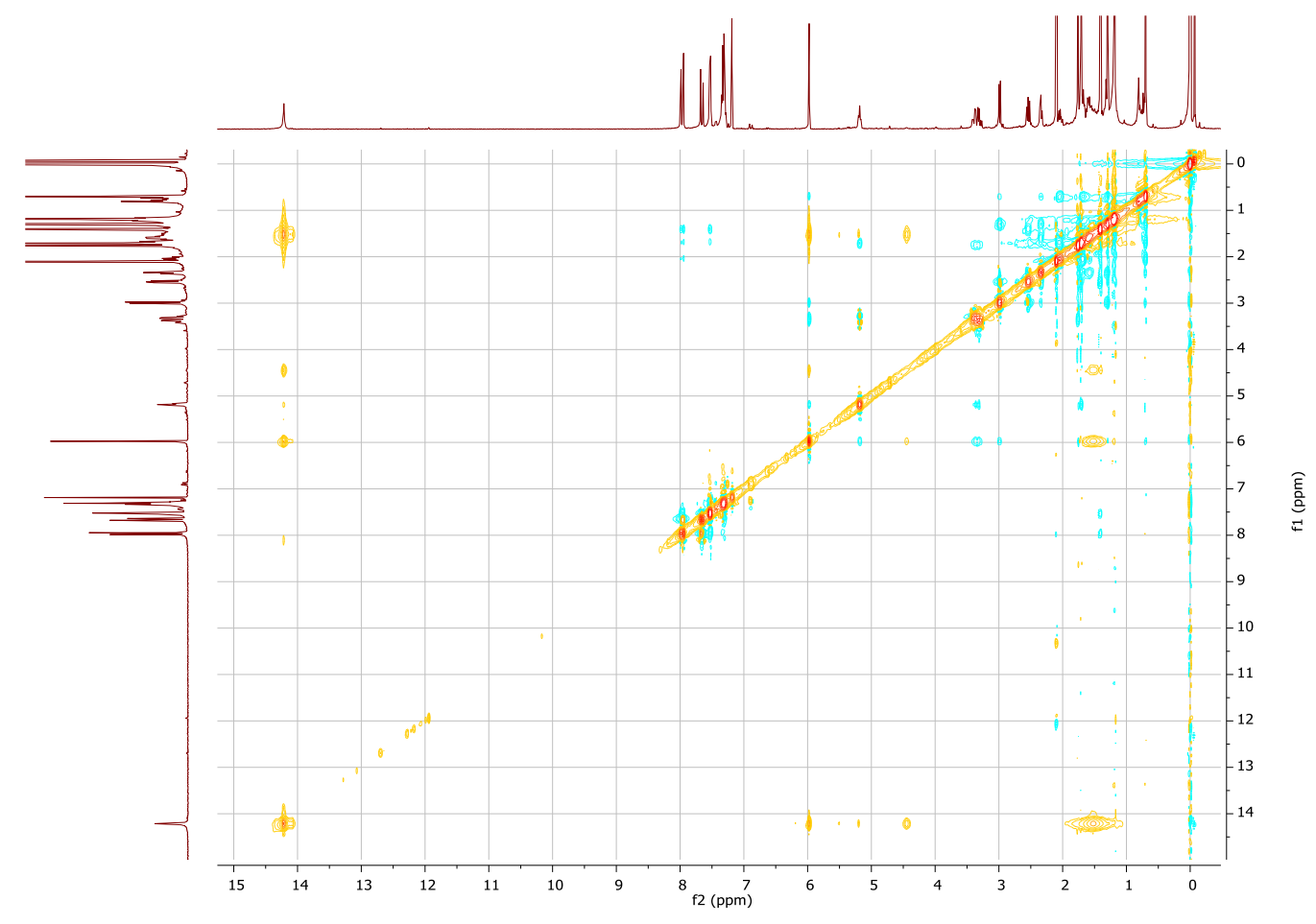

Figure S25. NOESY spectrum of 3.

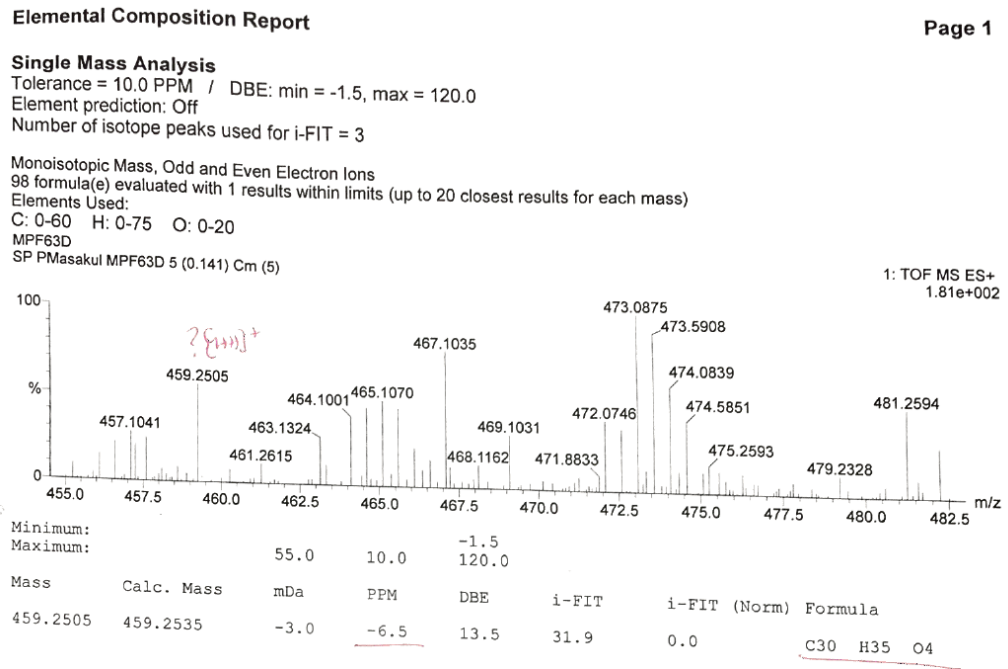

Figure S26. HRTOFESIMS spectrum of 3. 


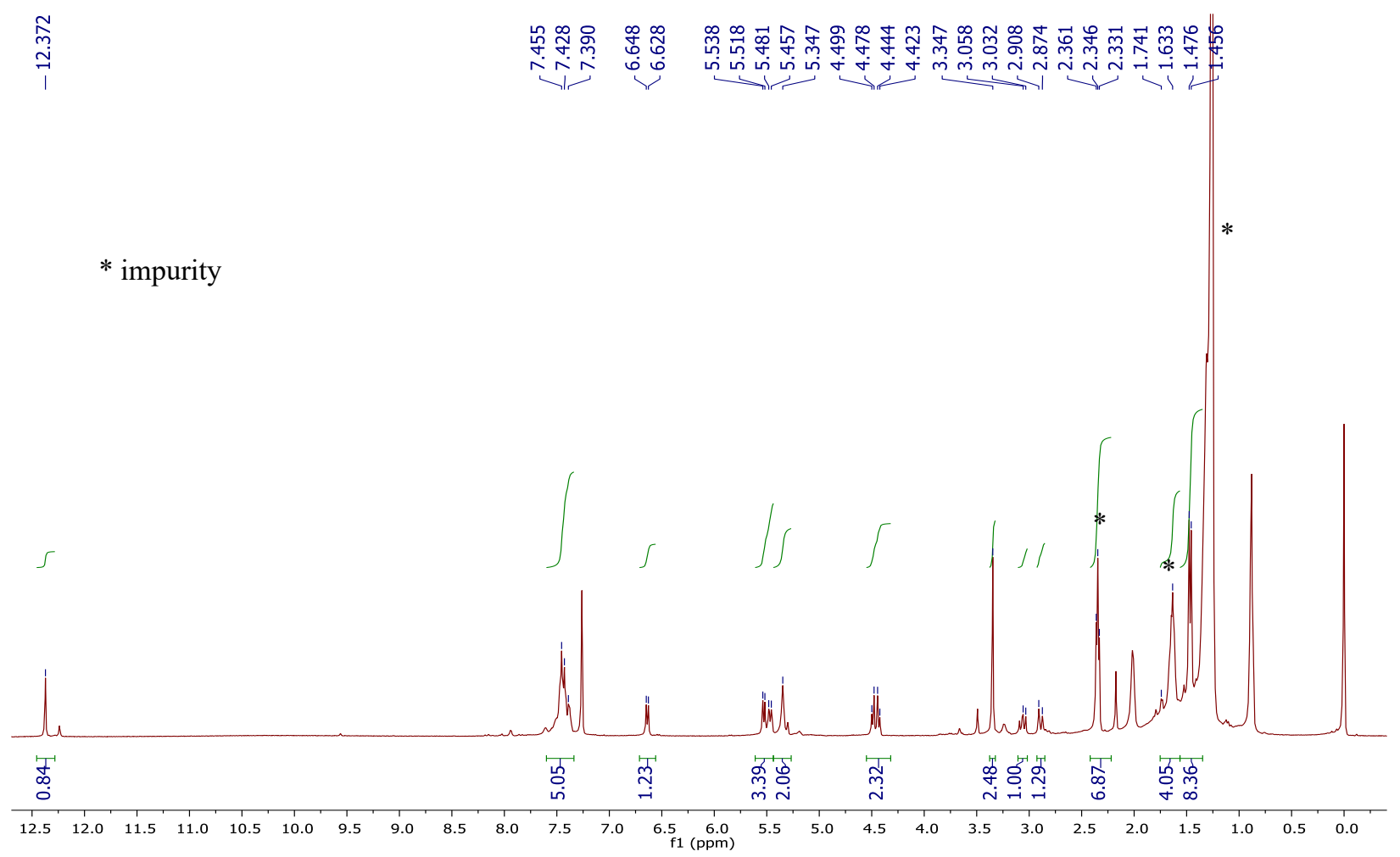

Figure S27. ${ }^{1} \mathrm{H}$ NMR (400 MHz, $\left.\mathrm{CDCl}_{3}\right)$ spectrum of 4.

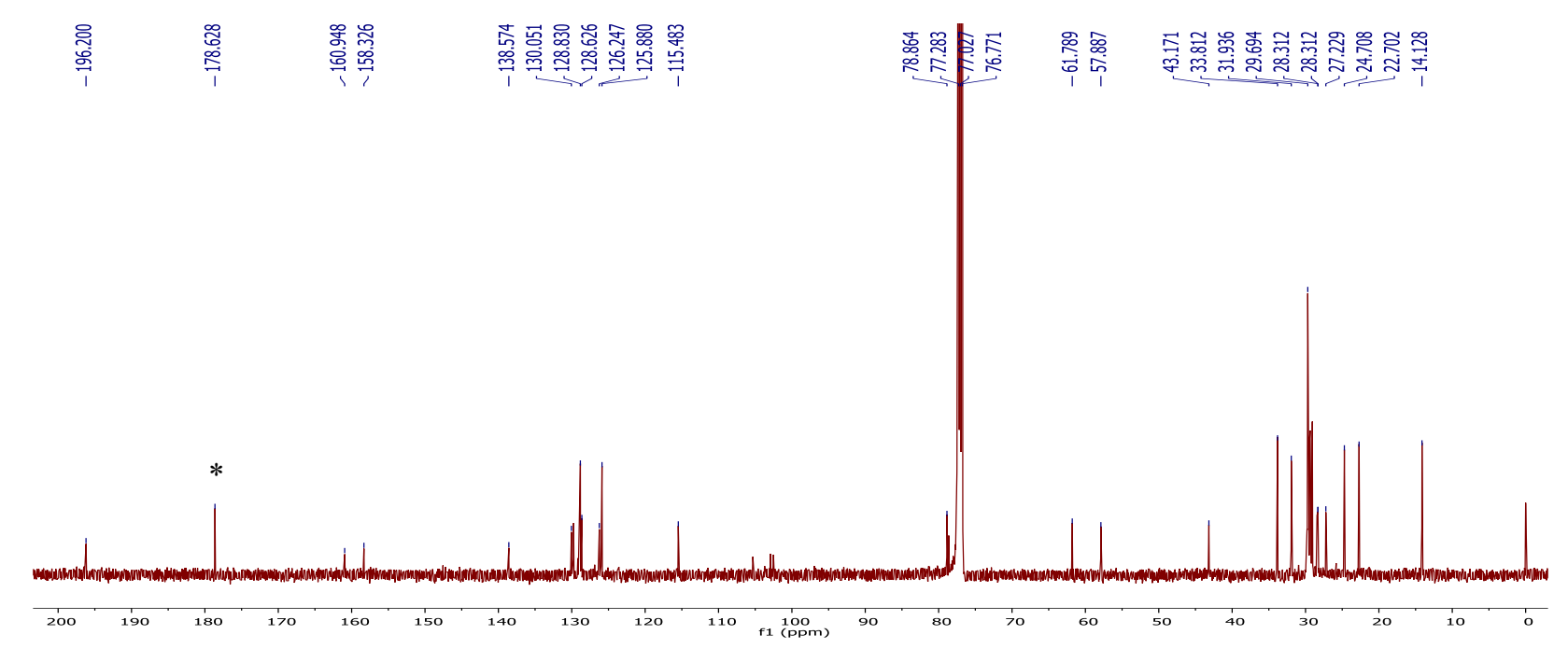

Figure S28. ${ }^{13} \mathrm{C}$ NMR $\left(100 \mathrm{MHz}, \mathrm{CDCl}_{3}\right)$ spectrum of 4. 


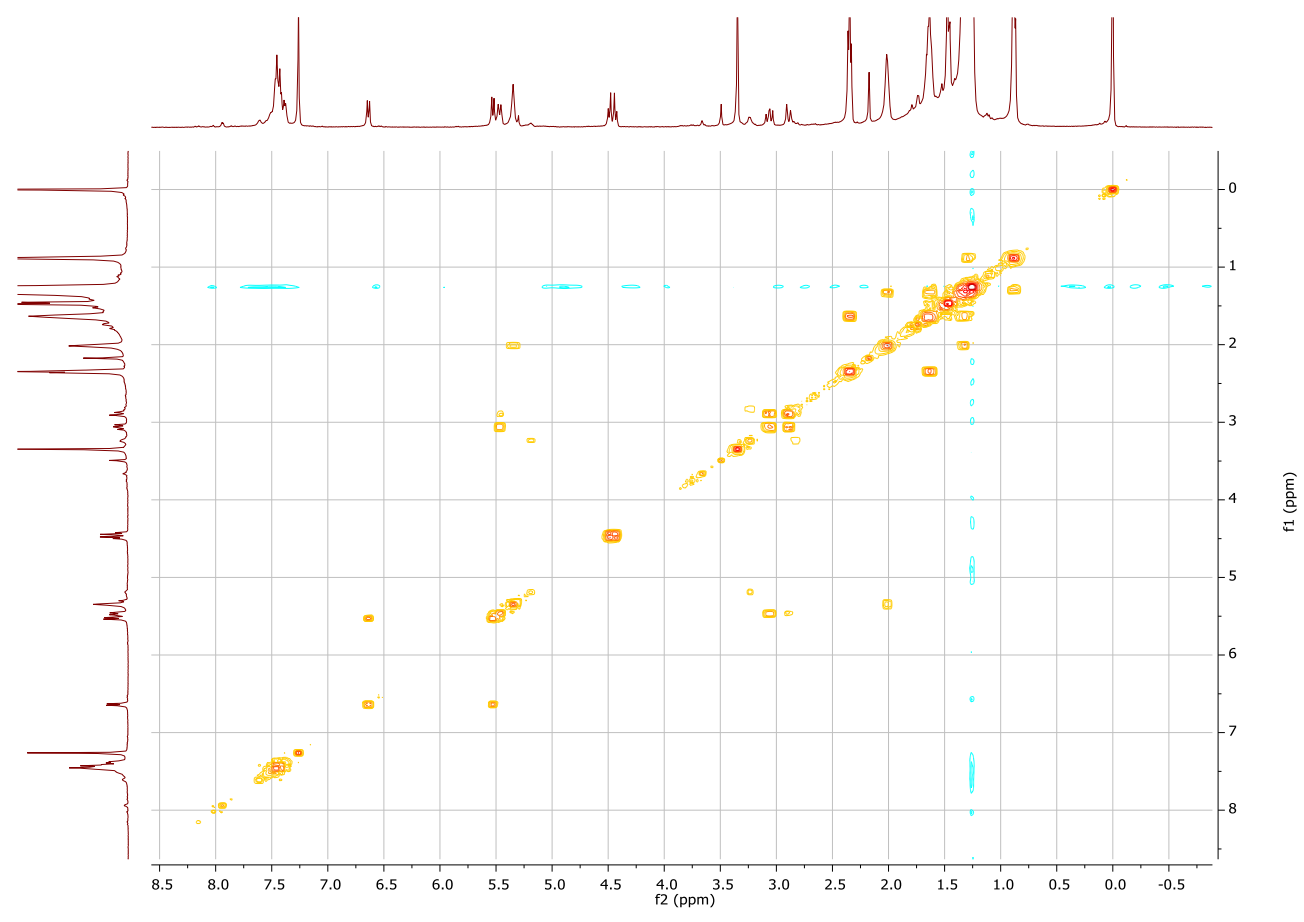

Figure S29. COSY spectrum of 4.

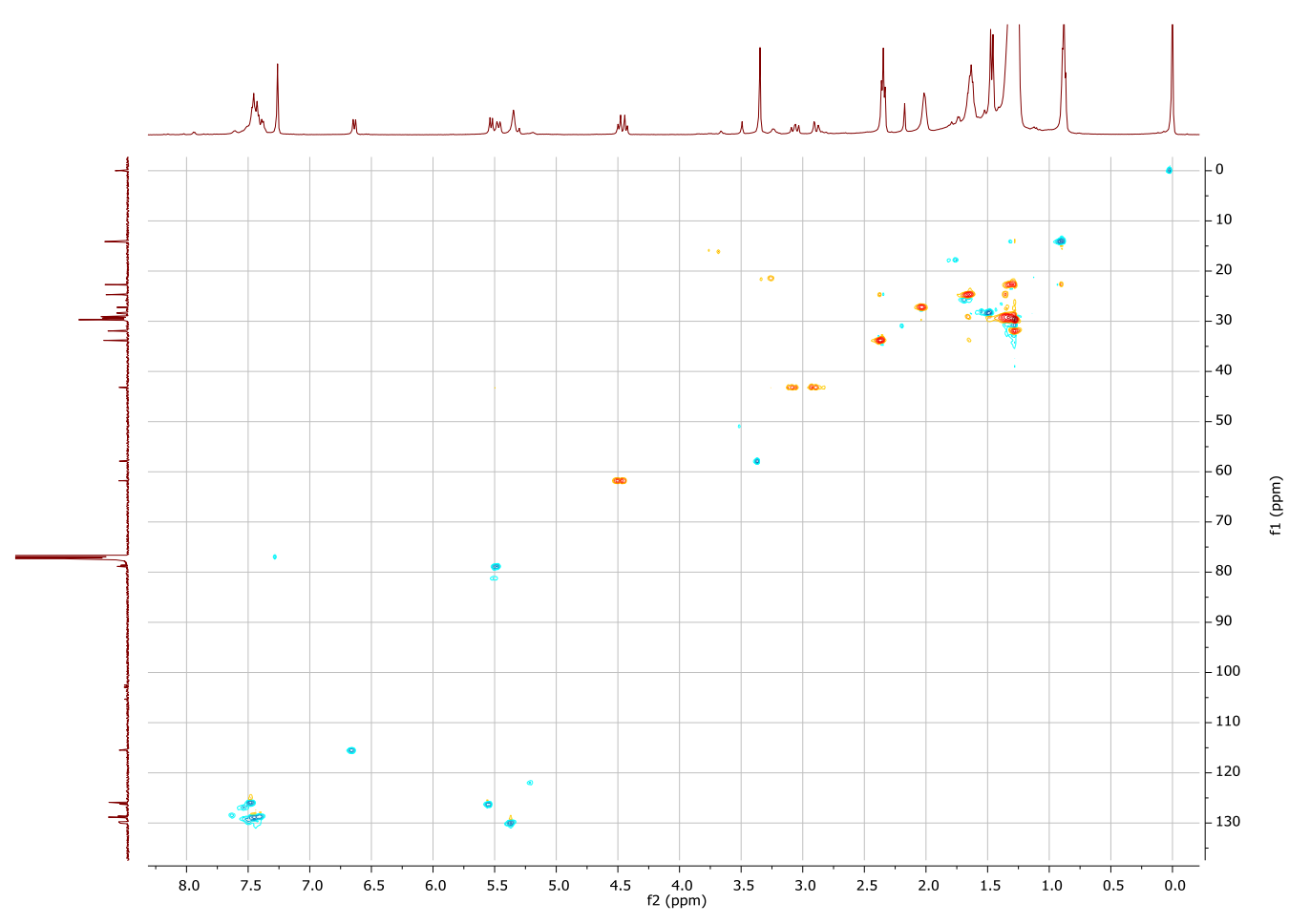

Figure S30. HSQC spectrum of 4. 


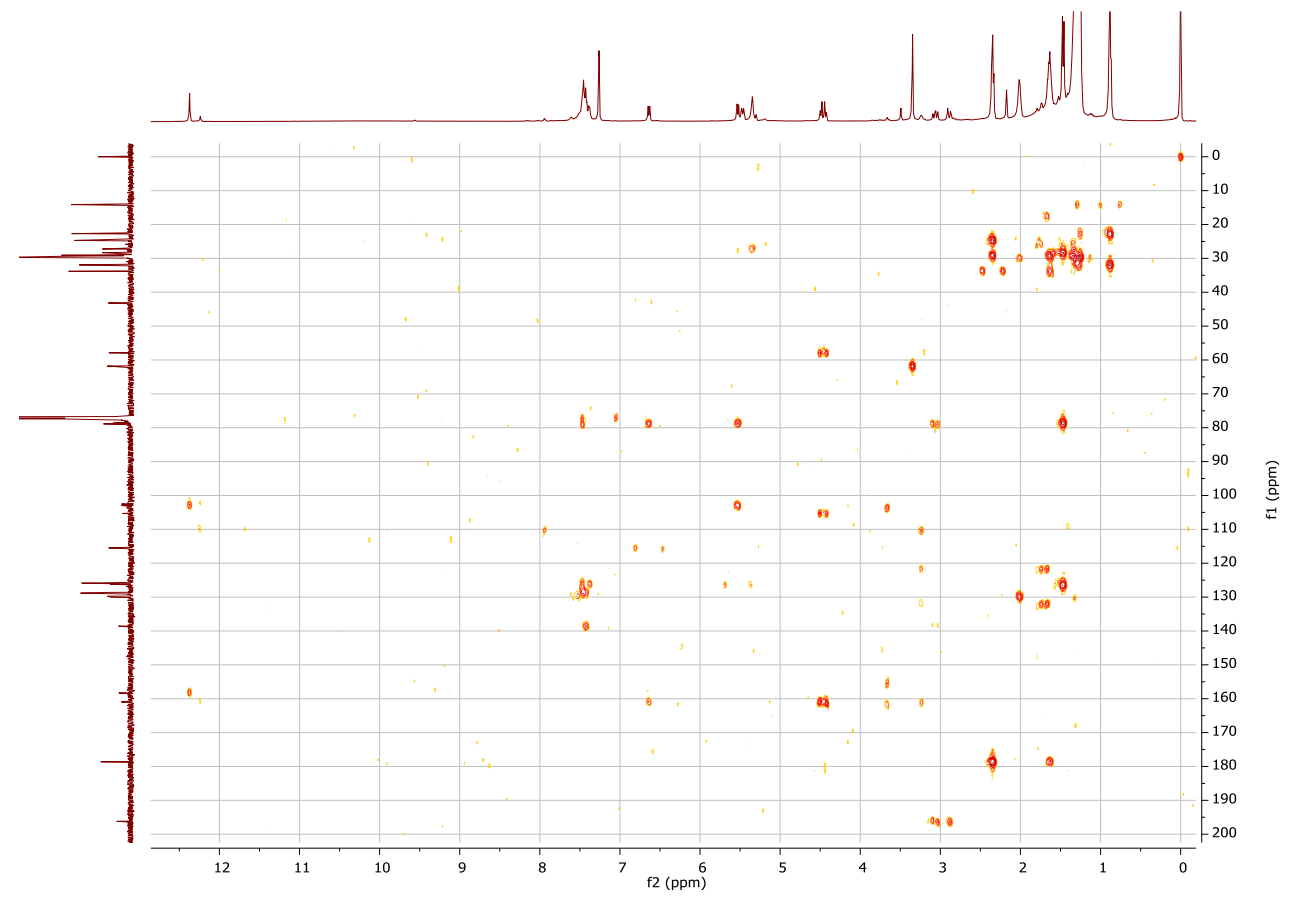

Figure S31. HMBC spectrum of 4.

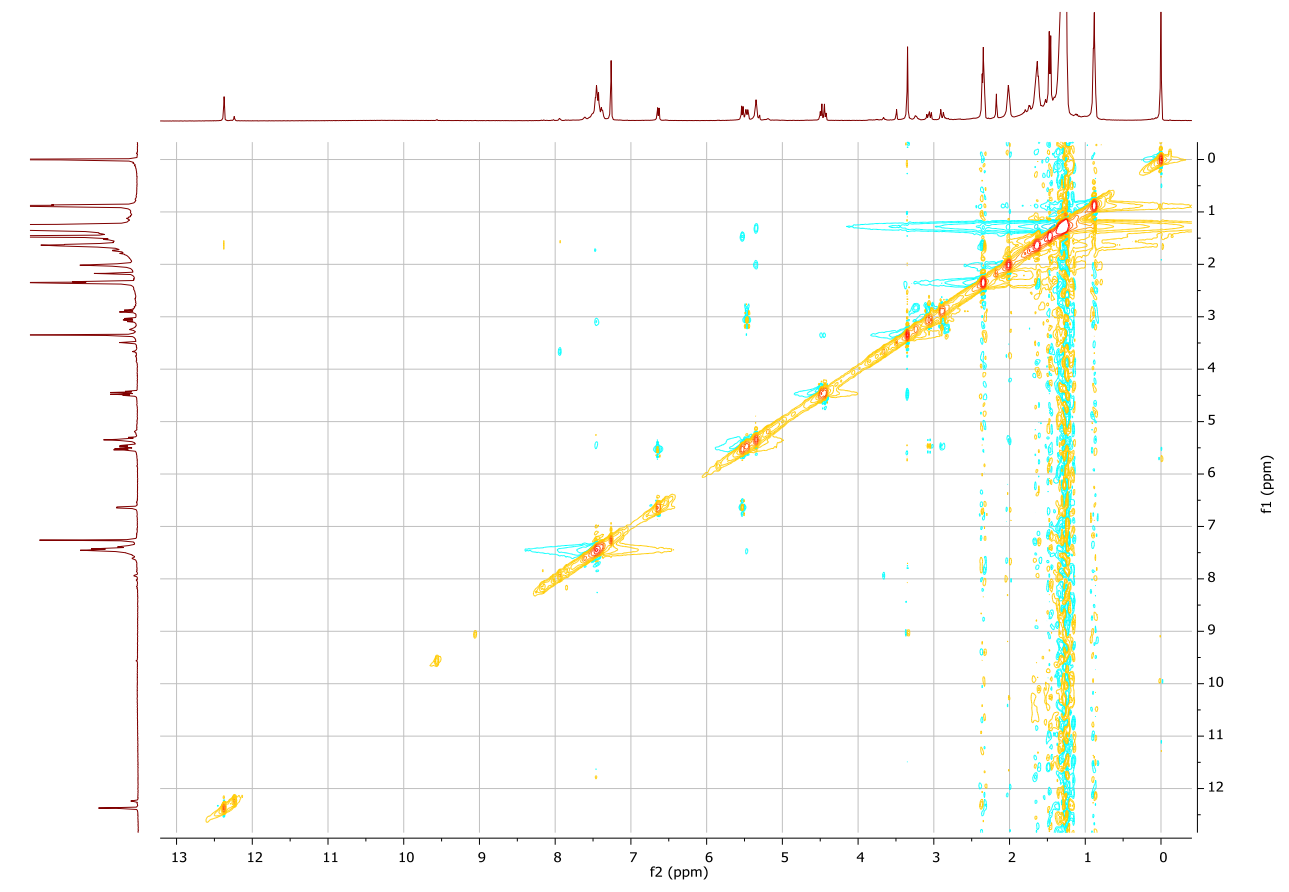

Figure S32. NOESY spectrum of 4. 


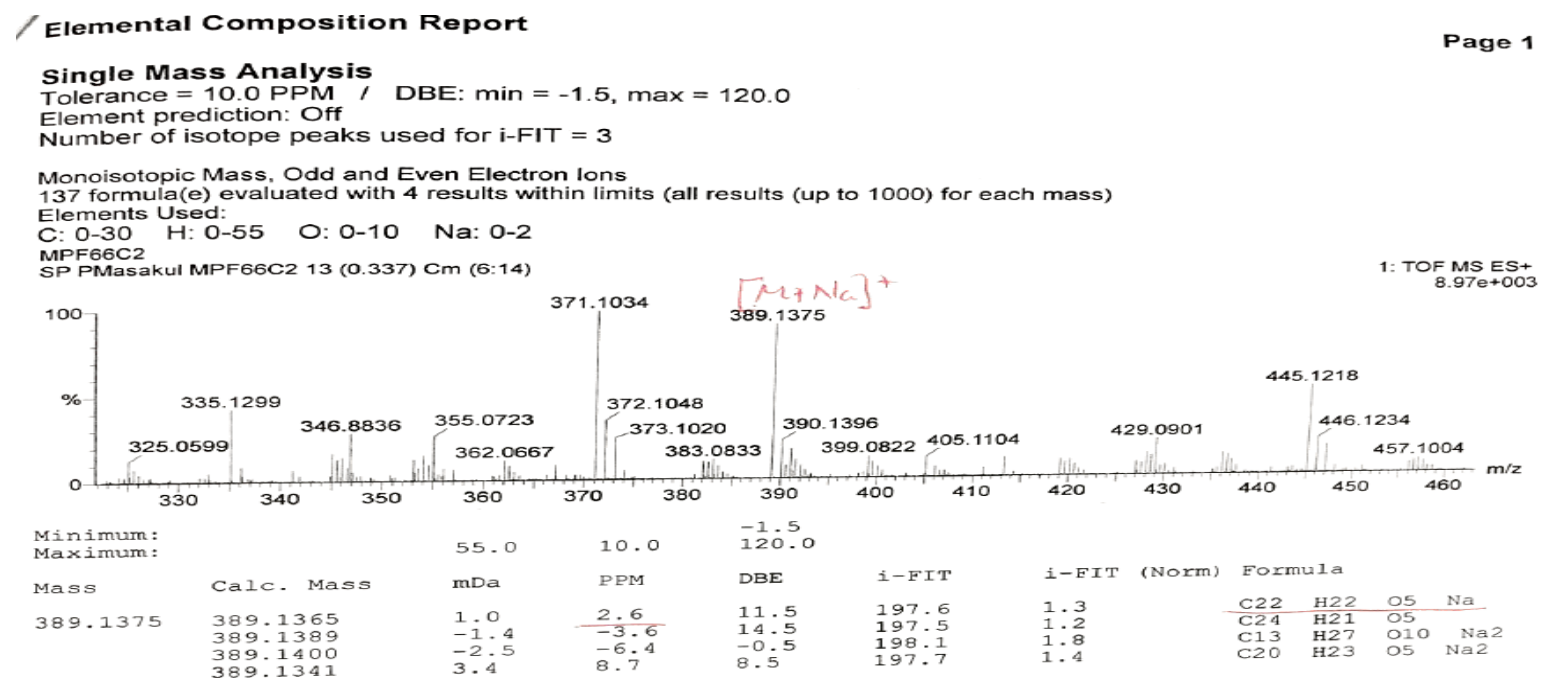

Figure S33. HRTOFESIMS spectrum of 4.

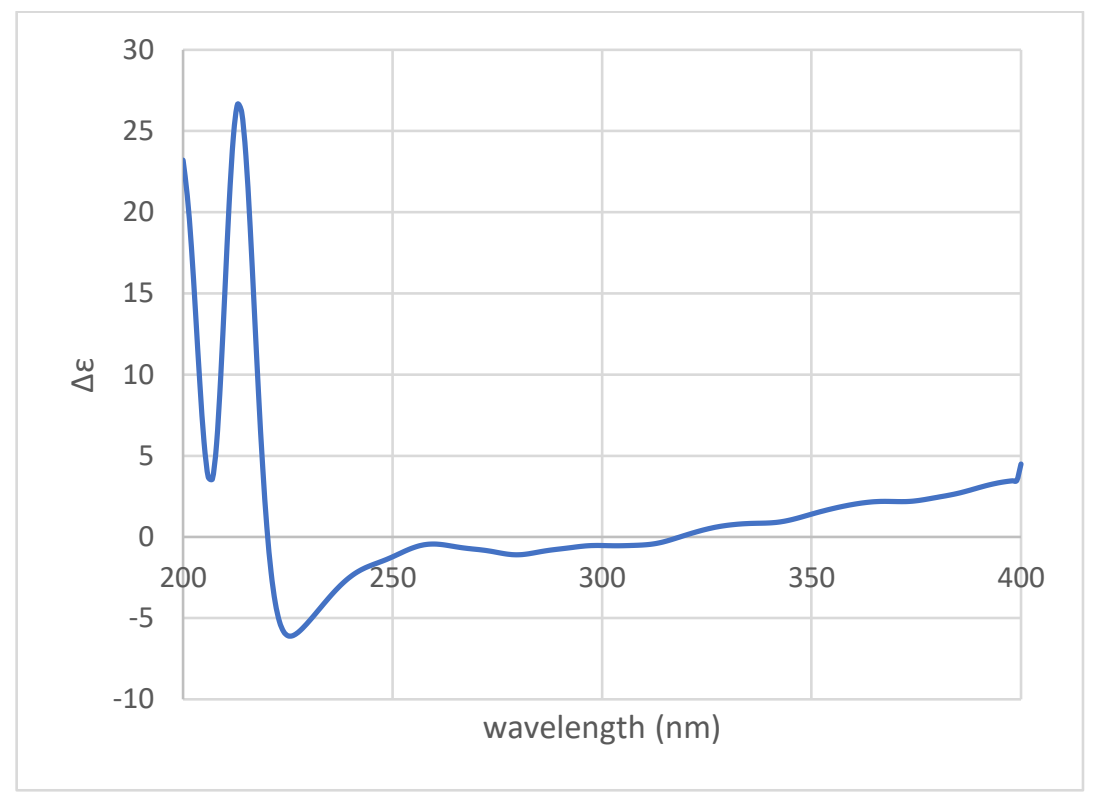

Figure S34. ECD spectrum of 4. 


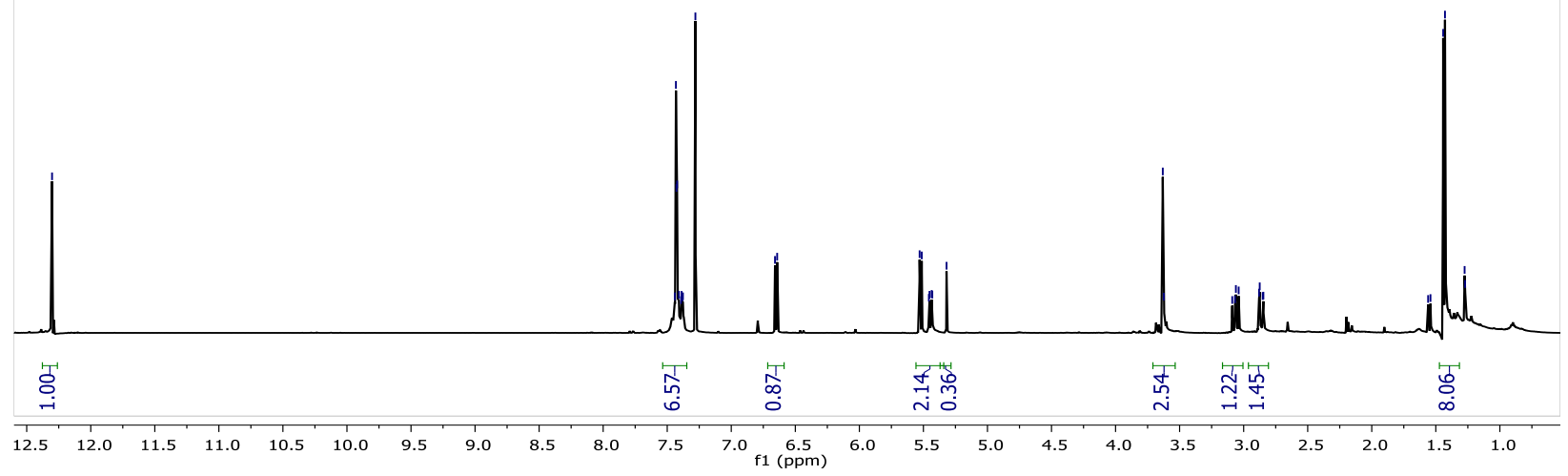

Figure S35. ${ }^{1} \mathrm{H}$ NMR $\left(600 \mathrm{MHz}, \mathrm{CDCl}_{3}\right)$ spectrum of 5.

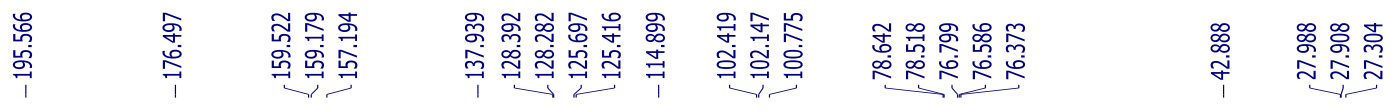

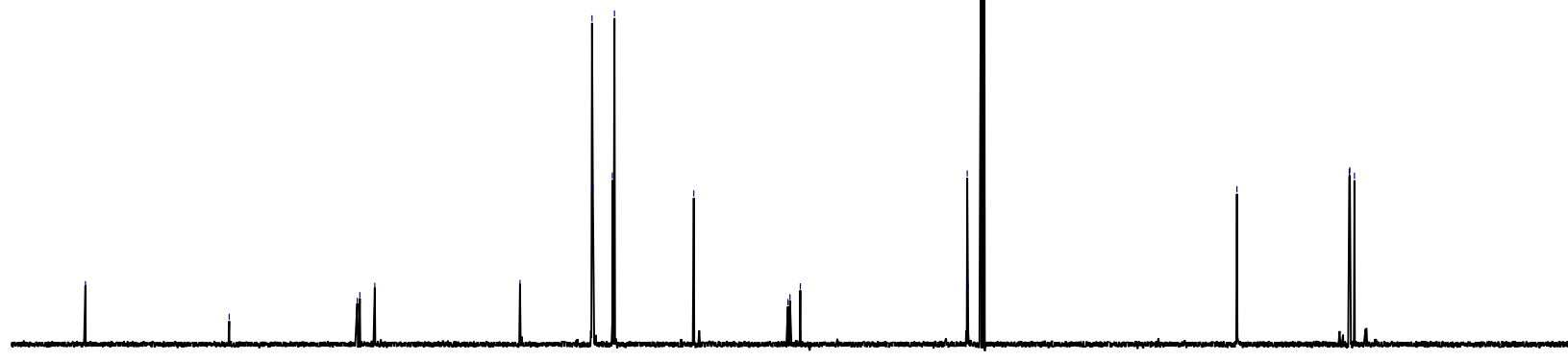

Figure S36. ${ }^{13} \mathrm{C}$ NMR $\left(150 \mathrm{MHz}, \mathrm{CDCl}_{3}\right)$ spectrum of 5 . 


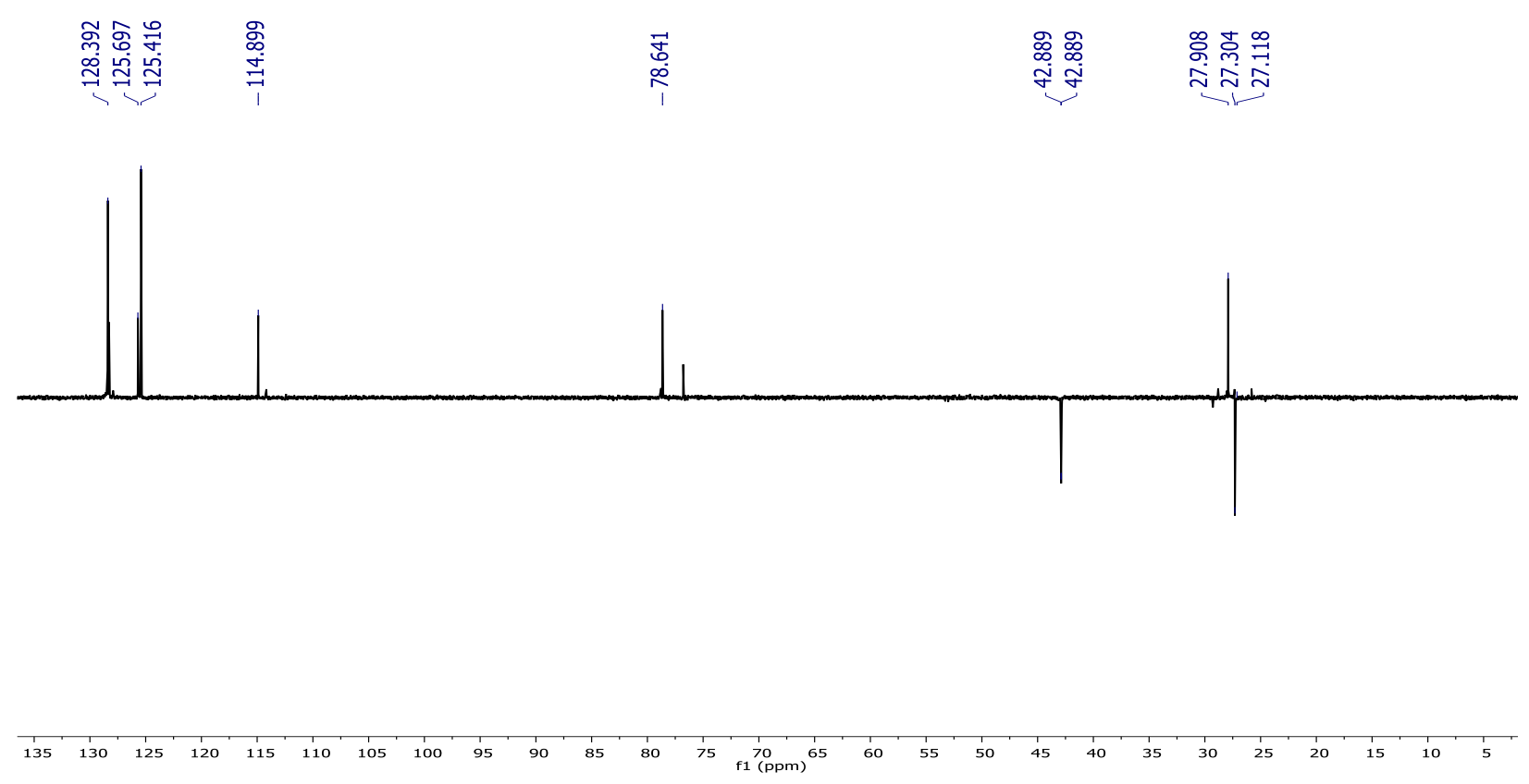

Figure S37. DEPT135 spectrum of 5.

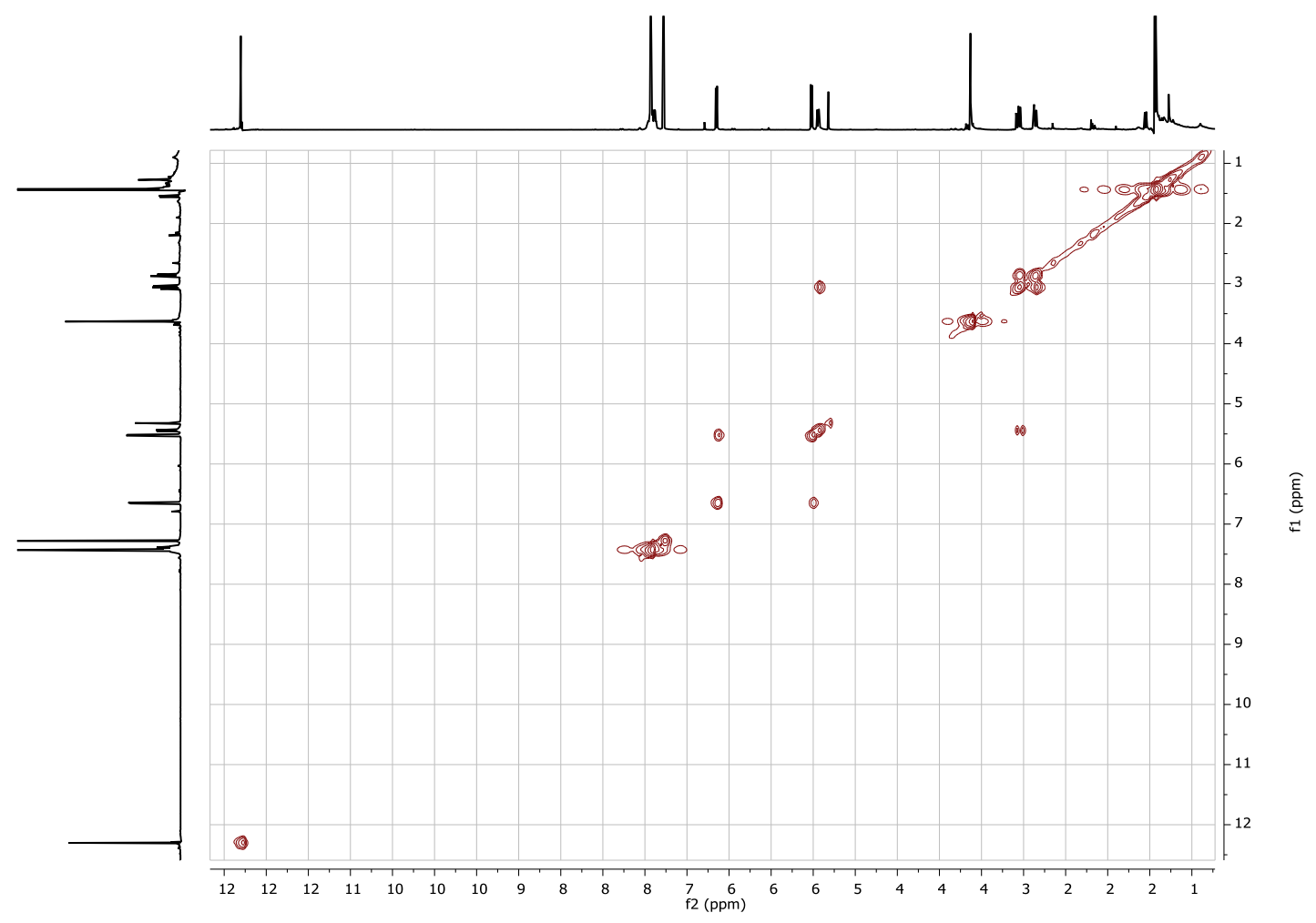

Figure S38. COSY spectrum of $\mathbf{5}$. 


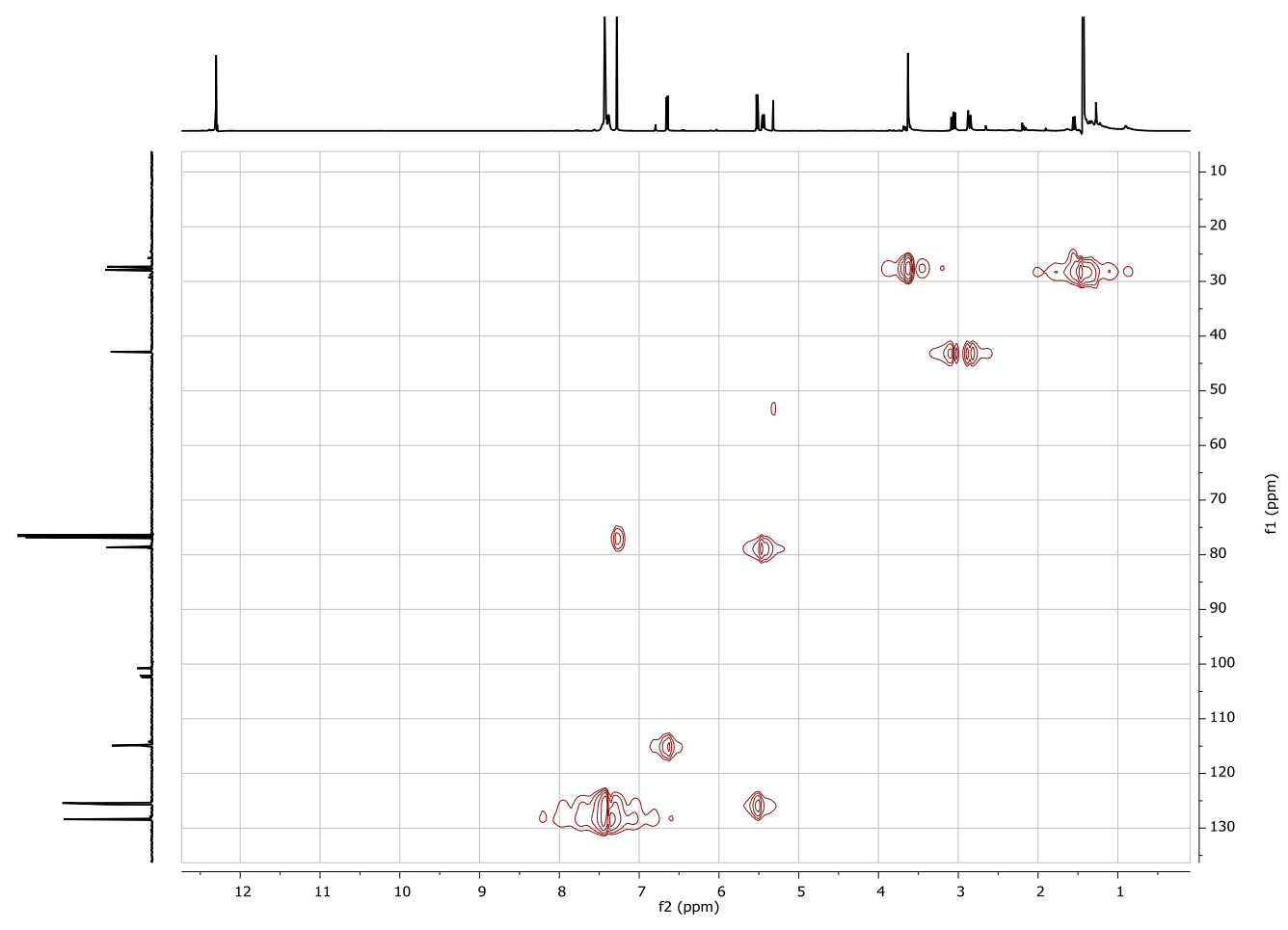

Figure S39. HSQC spectrum of 5.

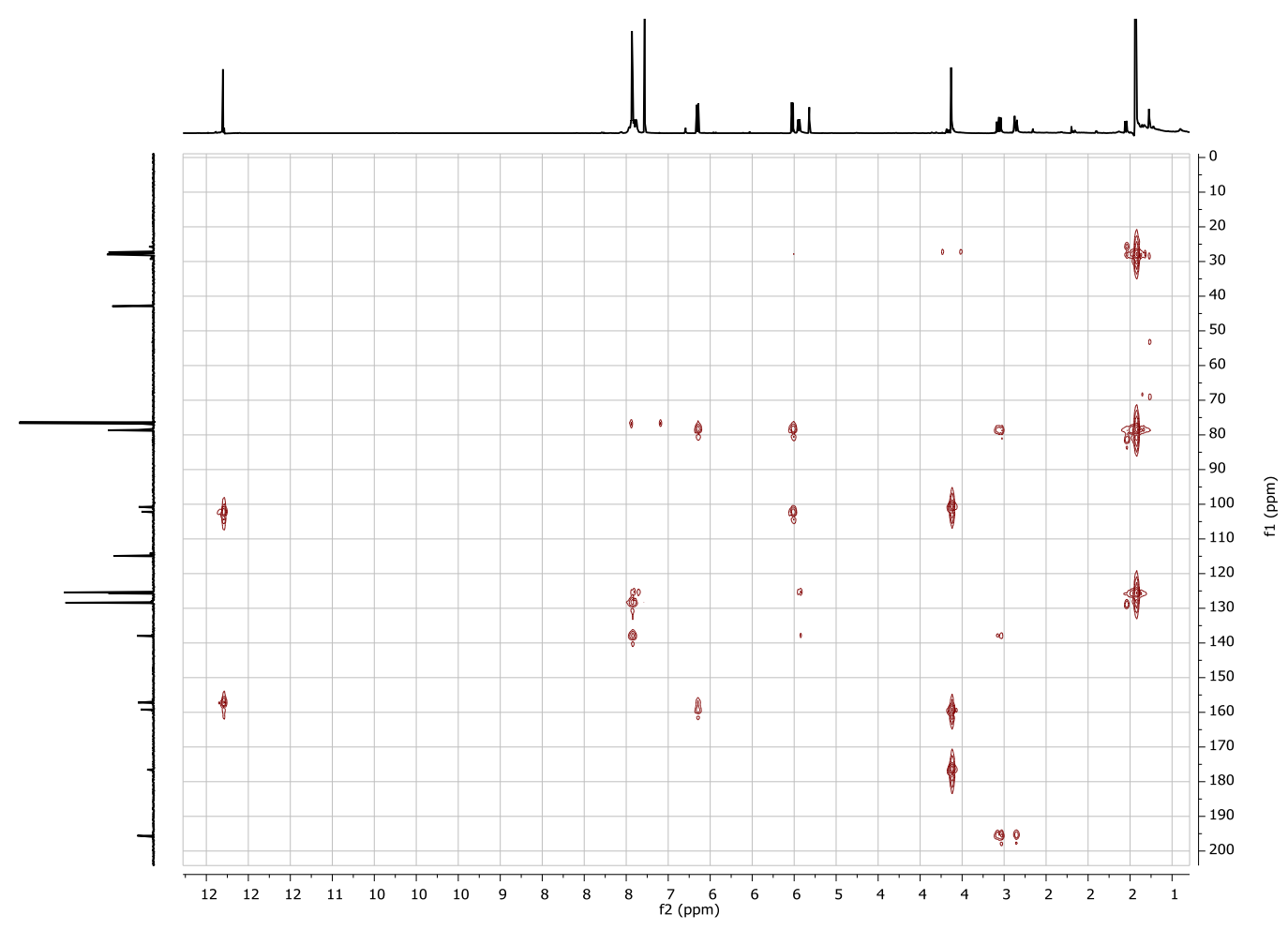

Figure S40. HMBC spectrum of 5. 
Selected filters: None

Monoisotopic Mass, Even Electron lons

954 formula(e) evaluated with 10 results within limits (all results (up to 1000) for each mass)

Elements Used:

$\begin{array}{llll}\text { C: } 0-50 & \mathrm{H}: 0-80 & \mathrm{~N}: 0-10 & \mathrm{O}: 0-10 \quad \mathrm{Na}: 0-1\end{array}$

EH11105 994 (17.373) AM (Cen,2, 30.00, Ht,5000.0,0.00,1.00); Cm (991:1006)

$100-\quad 381.1341$

TOF MS ES+

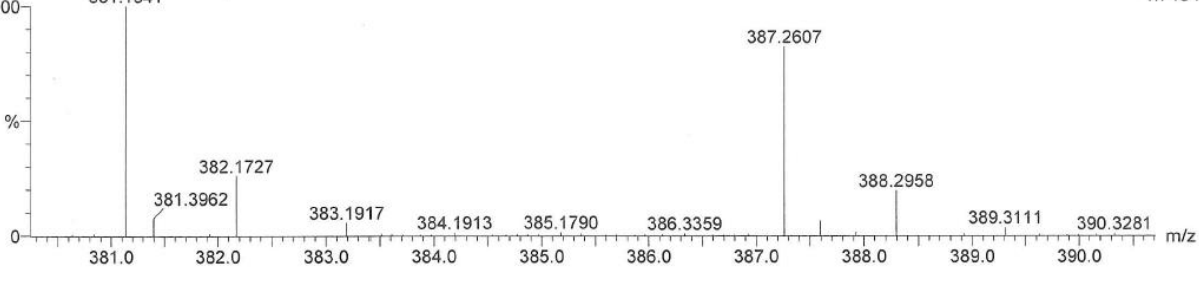

Minimum:

Maximum:

5.0

$10.0 \quad-1.5$
$\quad 80.0$

Mass

Calc. Mass

$\mathrm{mDa} \quad \mathrm{PPM}$

DBE

i-FIT

Formula

$381.1341 \propto 381.1338$

381.1346

$\begin{array}{ll}0.3 & 0.8 \\ -0.5 & -1.3 \\ -1.1 & -2.9\end{array}$

$\begin{array}{ll}0.8 & 12.5 \\ -1.3 & 1.5\end{array}$

$\begin{array}{ll}185.9 \\ 1.5 & 816.5\end{array}$

$\begin{array}{llllll}7.5 & 194.0 & \mathrm{C} 9 & \mathrm{H} 22 & \mathrm{~N} 6 & 09 \mathrm{Na}\end{array}$

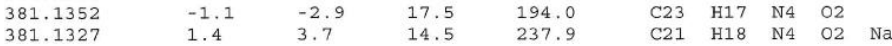

Figure S41. HRTOFESIMS spectrum of 5 .

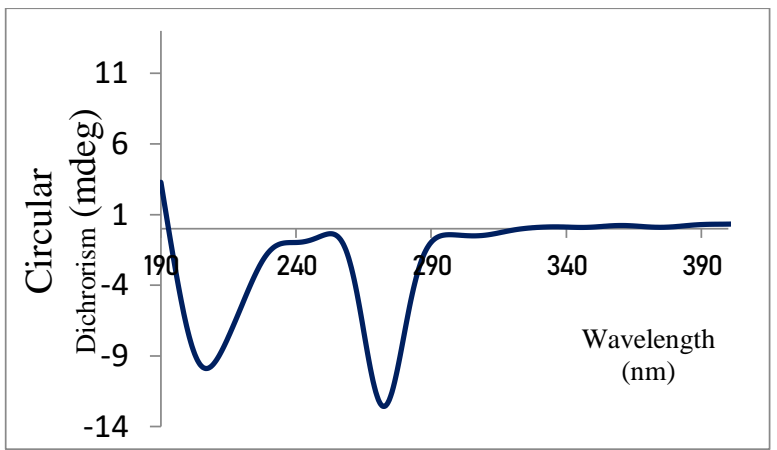

Figure S42. ECD spectrum of 5. 